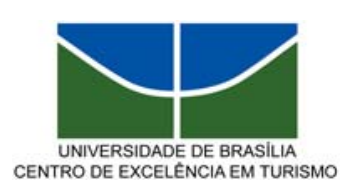

\title{
HÁBITOS E VALORES DE LAZER DA ELITE INTELECTUAL DE BRASÍLIA
}

ANA PAULA PRADO GONÇALVES

Brasília-DF, 2005. 


\section{Formulário de Orientação}




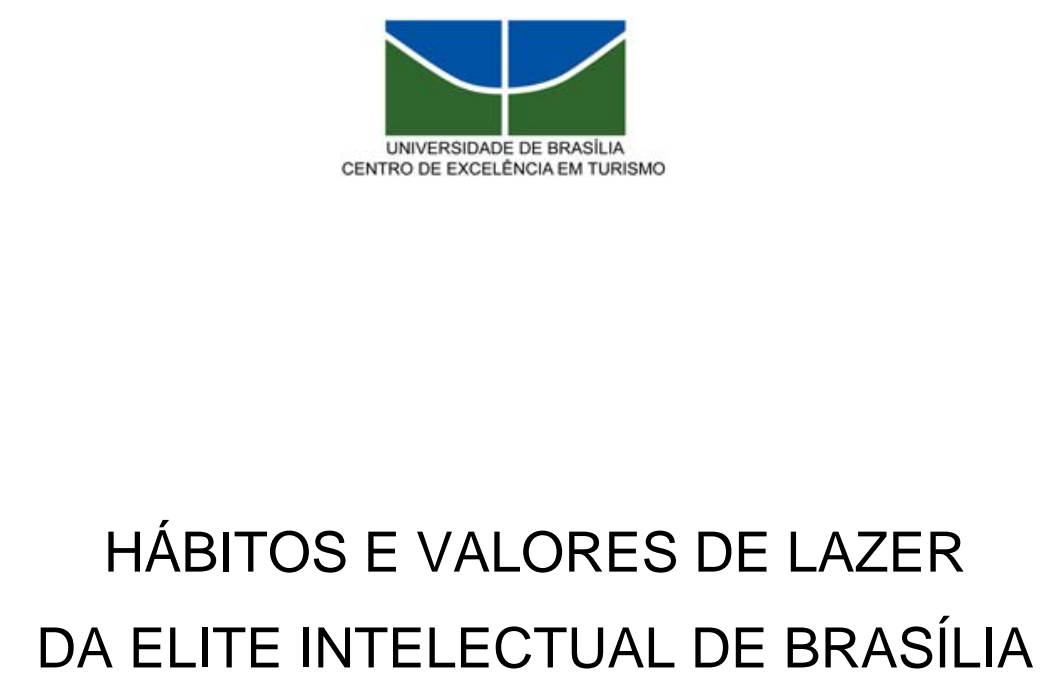

Ana Paula Prado Gonçalves.

Valquíria Padilha.

Monografia apresentada ao Centro de Excelência em Turismo da Universidade de Brasília como requisito parcial para a obtenção do certificado de Especialista em Turismo: Cultura e Lazer.

Brasília - DF, junho de 2005. 


\section{UNIVERSIDADE DE BRASÍLIA \\ Centro de Excelência em Turismo}

Curso de Especialização em Turismo: Cultura e Lazer

\section{HÁBITOS E VALORES DE LAZER \\ DA ELITE INTELECTUAL DE BRASÍLIA}

Ana Paula Prado Gonçalves

Banca Examinadora:

Prof.(a) Valquíria Padilha

Prof. (a) Deis Siqueira

Brasília, junho de 2005. 
Ao meu filho, Marcus Paulo Prado Rodrigues, que tanto amo e me motiva a lutar por um mundo melhor. 
Agradeço ao meu filho por existir em minha vida e aos meus pais, que tanto devo, e tão pouco pude até agora retribuir.

Agradeço à professora Orientadora Valquíria Padilha, por acreditar em minha pesquisa e por seu apoio e paciência, pois sem a sua ajuda este trabalho não teria se concretizado.

Outrossim, agradeço a todos que contribuíram, diretamente e indiretamente para a realização dessa pesquisa. 
Desejo também declarar que o pouco que aprendi até aqui é quase nada em comparação com o que ignoro e que não me desespero de aprender.

DESCARTES 


\section{RESUMO}

O estudo do lazer é uma área nova no Brasil, principalmente a ligação dele com o Turismo, visto que, anteriormente, era comum a análise do lazer, principalmente pela área de educação física. Com a introdução do Turismo no rol de cursos superiores, incluiu-se nele, também, o estudo sobre o lazer.

Esta pesquisa está sendo realizada dentro do curso de especialização em "Turismo: Cultura e Lazer", do Centro de excelência em Turismo, da Universidade de Brasília. Vale destacar que essa é a primeira turma desse curso, e é o primeiro curso de especialização de uma universidade pública de Brasília com o enfoque nos estudos sobre lazer e cultura.

Além disso, outro elemento de minha pesquisa também é pouco pesquisado trata-se da elite, mais especificamente, da elite intelectual.

Contudo, este trabalho, é uma análise sobre os hábitos de lazer da elite intelectual de Brasília, indo um pouco mais além de seu objetivo ao analisar como essa elite entende o lazer. 


\section{ABSTRACT}

The study of the leisure it is a new area in Brazil, mainly the linking of it with the Tourism, since, previously, the analysis of the leisure was common, mainly for the area of physical education. With the introduction of the Tourism in the roll of superior courses, it was included in it, also, the study on the leisure.

This research is being carried through inside of the course of specialization in "Tourism: Culture and Leisure ", of the Center of Excellency in Tourism, of the University of Brasilia. Valley to detach that this is the first group of this course, e is the first course of specialization of a public university of Brasilia with the approach in the studies on leisure and culture.

Moreover, another element of my research also little is searched is about the elite, more specifically, of the intellectual elite.

However, this work, it is an analysis on the habits of leisure of the intellectual elite of Brasilia, going a little more beyond its objective when analyzing as this elite it understands the leisure. 


\section{LISTA DE TABELAS}

Tabela 1- Destinos e motivos das viagens dos entrevistados, 53

Tabela 2- Lugares de lazer de Brasília mais freqüentados pelos entrevistados, 54

Tabela 3- Lazeres caros e baratos realizados pelos entrevistados, 56 


\section{LISTA DE GRÁFICOS}

Gráfico 1: Idades dos entrevistados, 44

Gráfico 2: Professores que possuem outra profissão, 44

Gráfico 3: Faixa salarial dos entrevistados, 45

Gráfico 4: Grau de instrução dos entrevistados, 45

Gráfico 5: Grau de instrução dos pais dos entrevistados, 46

Gráfico 6: Grau de instrução das mães dos entrevistados, 46

Gráfico 7: Quantidade de aparelhos de TV por residência, 47

Gráfico 8: Quantidade de aparelhos de telefone fixo em casa, 47

Gráfico 9: Quantidade de telefone celular por entrevistado, 48 


\section{LISTA DE SIGLAS}

DF - Distrito Federal

GDF - Governo do Distrito Federal

IDH - Índice de Desenvolvimento Humano

JK - Juscelino Kubitschek

ONU - Organização das Nações Unidas

PIB - Produto Interno Bruto

RA - Região Administrativa

SETUR DF - Secretária de Turismo do Distrito Federal

UNB - Universidade de Brasília

UNESCO - United Nations, Educational, Scientific and Cultural Organization 


\section{SUMÁRIO}

RESUMO, VI

ABSTRACT, VII

LISTA DE TABELAS, VIII

LISTA DE GRÁFICOS, IX

LISTA DE SIGLAS, $X$

INTRODUÇÃO, 13

1 UM OLHAR PARA BRASÍLIA, CAPITAL DO BRASIL, 15

1.1 Breve história da construção de Brasília, 16

1.2 Brasília, patrimônio da humanidade, 17

1.3 Brasília em números, 19

1.4 Turismo em Brasília , 21

2 CONCEITUANDO TEMPO LIVRE, LAZER E ÓCIO, 22

2.1 Tempo livre, 25

2.2 Ócio, 26

2.3 Lazer, 28

2.4 Abordagens teóricas do lazer, 31

3 APONTAMENTOS TEÓRICOS SOBRE ELITE, 32 
3.1 Teoria das Elites, 37

3.2 Elite intelectual, ou a intelligentsia, 40

4 CAMINHOS PERCORRIDOS E ANÁLISE DAS ENTREVISTAS, 43

4.1 Perfil socioeconômico dos entrevistados, 45

4.2 Valores dos entrevistados em torno do lazer, 49

4.3 Hábitos de lazer dos professores da Universidade de Brasília, 53

CONSIDERAÇÕES FINAIS, 57

REFERÊNCIAS, 59

Bibliográfica, 59

CDs, 63

Sites, 63

APÊNDICE A - ROTEIRO DA ENTREVISTA, 64

APÊNDICE B - MAPA DE BRASÍLIA, 69 


\section{INTRODUÇÃO}

A pesquisa apresentada nessa monografia tem como foco central os hábitos e os valores que a elite intelectual de Brasília relatam ter. Nesse estudo, a elite intelectual de Brasília é representada por professores universitários da Universidade de Brasília - UnB.

Os motivos que me levaram a estudar este tema foram, além do fato de haver carência de estudos no Brasil sobre esse tema - que é adequado ao tema geral do curso de especialização em cujo programa se desenvolveu essa monografia - por referir-se à cidade de Brasília, local onde nasci e vivo .

Essa pesquisa pretendeu responder à seguinte pergunta: 0 que indivíduos pertencentes a um grupo da elite intelectual da Capital do Brasil fazem no seu tempo livre? Como concebem e valoram lazer? Assim, os objetivos principais desse estudo foram: identificar indivíduos que façam parte da elite intelectual de Brasília; identificar os hábitos de lazer da elite intelectual de Brasília e conhecer a concepção e os valores que os membros dessa elite demonstram ter sobre lazer.

A metodologia adotada para atingir os objetivos foi a seguinte: trata-se de uma pesquisa qualitativa que envolve um levantamento bibliográfico em torno dos temas do lazer, da elite e de Brasília. Além disso, foram feitas entrevistas semi-estruturadas com um grupo identificado como elite intelectual da cidade de Brasília, que corresponde a um 
professor universitário de cada curso da Universidade de Brasília e que more em Brasília há pelo menos 5 (cinco) anos. Em função dos limites impostos pelo tempo, nem todos os cursos da UnB foram envolvidos nas entrevistas. Os professores entrevistados trabalham, são lotados, nos seguintes cursos: enfermagem, nutrição, medicina, ciência política, direito, relações internacionais, geologia, educação física, engenharia elétrica, arquitetura, lingüística, matemática, computação e música.

o primeiro capítulo dessa monografia trata de Brasília, que é o locus da investigação, abordando a história da cidade; a transformação da cidade em patrimônio cultural; dados que diferenciam Brasília do Distrito Federal e o turismo na capital federal.

0 capítulo 2 apresenta um dos conceitos básicos que fundamentam esta pesquisa, focando, especialmente o lazer e as diferenças entre lazer, ócio e tempo livre.

0 terceiro capítulo aborda a teoria das elites, diferenciando-a de casta dirigente, aristocracia, estamento e primeira classe política. Com um enfoque na elite intelectual, ou intelligentsia.

0 quarto e último capítulo da monografia trata da metodologia adotada e faz a análise dos dados colhidos em entrevistas.

Nas considerações finais são apontadas algumas das conclusões alcançadas com a pesquisa realizada. 


\section{UM OLHAR PARA BRASÍLIA, A CAPITAL DO BRASIL}

Brasília, Patrimônio Cultural da Humanidade, capital do Brasil. Esta belíssima primazia arquitetônica está localizada no Planalto Central Brasileiro, tendo sido construída em quatro anos, durante o governo do presidente Juscelino Kubitschek e inaugurada no dia 21 de abril de 1960.

É uma cidade planejada. Seu projeto arquitetônico foi escolhido por meio de um concurso, cujo projeto vencedor foi o de Lúcio Costa. A união deste urbanista, do arquiteto Oscar Niemeyer e do paisagista Burle Marx, resultou, sem sombra de dúvida, em uma cidade moderna e digna dos elogios que recebe. De acordo com Braga e Falcão (1997:10), "Sua grande virtude foi o equilíbrio entre a esfera residencial e administrativa, representada pelos dois eixos que se cruzam." Estes eixos $^{1}$ são exatamente o Eixo Monumental e o Eixo Rodoviário. Complementando o pensamento dos referidos autores, Gouvêa (1998:44) diz o seguinte:

A cidade foi concebida tendo como estrutura básica dois eixos: o eixo Monumental e o Rodoviário. No Eixo Monumental se concentram os edifícios nos quais se desenvolvem as atividades administrativas, tanto as federais como as distritais, intercalados por amplas áreas verdes, onde a natureza se representa domada sob a forma de gramados, mas que permitem a não impermeabilização do solo, funcionando positivamente para conter erosões. No encontro dos dois eixos, as funções de serviços (setores comercial / hospitalar / bancário / diversões) e no Eixo Monumental se estende de forma setorizada a atividade residencial e pequenas áreas destinadas ao comércio local.

Sob o olhar de Bicca (1997:10),

\footnotetext{
${ }^{1}$ Encontrá-se anexado o desenho desses eixos.
} 
Brasília é, sem dúvida, uma cidade singular, distinta de todas as demais. E esta afirmação não é válida apenas pela sua óbvia diferença em relação às chamadas cidades tradicionais, pois ela também procede quando a comparamos, ainda hoje, com as cidades modernas ditas planejadas. Brasília foi e continua única, mesmo que na sua concepção estejam explicitamente presentes os ideais modernistas encontrados também na grande maioria das demais experiências significativas do urbanismo do séc. $X X$. Mas a estas semelhanças, importantes, é verdade, se somam diferenças não menos expressivas, resultantes da forma como Brasília foi conceituada na sua gênese, responsável sem dúvida pela inconteste vitória do arquiteto Lúcio Costa no concurso para a escolha do projeto urbanístico da Nova Capital do Brasil.

É justamente essa singularidade na arquitetura de Brasília que fez a Unesco (United Nations, Educational, Scientific and Cultural Organization) reconhecê-la como Patrimônio Cultural da Humanidade. Nessa perspectiva, assinala Gouvêa (1998:44): "Brasília se constitui como o exemplo mais completo das propostas modernistas, sendo inclusive inscrita pela UNESCO como patrimônio da Humanidade, basicamente por ser o exemplo acabado e vivo do urbanismo moderno."

\subsection{Breve história da construção de Brasília}

Em 1500, o navegador português Pedro Álvares Cabral chegou ao Brasil e deu início a um longo processo de colonização deste país pelos seus patrícios. Em 1548, D. João $\|^{2}$ tomou a iniciativa de estabelecer um governo no Brasil, sendo a Baía de Todos os Santos $^{3}$ o local escolhido para ser a sede do governo colonial (Vitor, 1980). Em 1808; por força da ameaça napoleônica em terras portuguesas, que de lá expulsou a família real, ocorreu a transferência da sede do governo colonial para a cidade de São Sebastião, no Estado do Rio de Janeiro, sendo que, posteriormente, com a Independência do Brasil, aquele Estado veio a sediar a capital do Brasil (Vitor, 1980).

Porém desde o fim da era colonial, durante os dois reinados até os 66 anos da República (1955), havia a idéia de interiorização da Capital do Brasil ${ }^{4}$. Fato que só ocorreu em 1956 com a construção de Brasília (Oliveira, 1975). Os argumentos

\footnotetext{
${ }^{2}$ Rei de Portugal.

${ }^{3}$ Atualmente conhecida como Salvador, a capital do Estado da Bahia.

${ }^{4}$ A primeira idéia de transferência da Capital do Brasil surgiu em 1789.
} 
utilizados para a transferência da Capital do Brasil - que até então era o Rio de Janeiro - para o interior do Brasil foram vários, dentre os quais Kent (1956), Evenson (1973), Goslin (1979), Farret (1978), citados por Farret (1985:18) registram os seguintes:

primeiro, uma tentativa de apagar todos os vestígios e símbolos da dominação portuguesa, como seria, no caso, a cidade do Rio de Janeiro; segundo, uma medida destinada a transformar o Brasil num país unificado, ao invés de um grande número de enclaves; terceiro, por razões de defesa nacional, uma vez que a Capital seria altamente vulnerável a ataques estrangeiros; quarto, um meio de promover novos padrões de eficiência no serviço público; quinto, um instrumento ideológico capaz de criar, junto às massas, um espírito de identidade nacional; sexto, um centro de crescimento capaz de promover o desenvolvimento regional do Centro-Oeste, através da criação de um significativo mercado consumidor e da introdução de inovações tecnológicas, econômicas e sociais; e sétimo, como uma porta de entrada à ocupação econômica das fronteiras oeste e norte do país.

Além dos argumentos apresentados, ainda se diz que a transferência da Capital do Brasil só ocorreu nos idos de 1950, tendo em vista, na concepção de Silva $^{5}$ (apud FARRET, 1971:7), "uma vertente explicativa, centrada numa curiosa combinação de ufanismo com misticismo, que coloca a nova Capital como produto de uma epopéia de bandeirantes modernos cumprindo os desígnios eternos manifestados na visão profética de Dom Bosco ${ }^{6}$." Outra versão, mais realista, e defendida por Farret (1985:18) aponta para a ocupação do hinterland como "vital à soberania e ao desenvolvimento nacional."

\subsection{Brasília, patrimônio da humanidade}

O planejamento urbano, a arquitetura moderna, o traçado singular representativo de uma aeronave traduz o caráter especial dessa metrópole. Esta junção de qualidades culminou, em 1987, no reconhecimento pela Unesco, como Patrimônio Cultural da Humanidade, sendo a primeira cidade no mundo a receber esse título. Nesse sentido, ressalta-se o que está dito a seguir:

\footnotetext{
${ }^{5}$ Cf. SILVA, Ernesto (1971). História de Brasília.

${ }^{6}$ Trata-se de um sacerdote, que no ano de 1873 teve um sonho no qual teria antevisto o surgimento de Brasília. Conferir mais informações no anexo.
} 
O reconhecimento de seu valor patrimonial fundamentou-se no plano urbanístico de Lúcio Costa, concebido em quatro escalas estruturais: a Monumental - compreendida em todo o Eixo Monumental e que abriga a alma político-administrativa do País; a Gregária - representada por todos os setores de convergência da população -; a Residencial - composta pelas Superquadras Sul e Norte - e a Bucólica - que permeia as outras três, por se destinar aos gramados, praças, áreas de lazer, orla do lago Paranoá e aos jardins tropicais de Burle Marx.

Da interação dessas quatro escalas nasceu uma cidade que, "sendo monumental, é também cômoda, eficiente, acolhedora e íntima. É ao mesmo tempo, derramada e concisa, bucólica e urbana, lírica e funcional..." (LÚCIO COSTA) ${ }^{7}$.

Sendo assim, de acordo com Peralva (1988:35-37), o que é preservado em Brasília, para manter-se como Patrimônio da Humanidade, é o que segue:

- A praça dos Três Poderes fica preservada tal como se encontra.

- Os terrenos do canteiro central do eixo monumental são considerados non-aedificand nos trechos entre o Congresso Nacional e a Rodoviária, desta até a torre de TV e no trecho não ocupado entre a torre e a praça do Buriti.

- A Esplanada dos Ministérios é de uso exclusivo dos ministérios do governo federal, embora admita-se a construção de um pavimento em nível de mezanino sobre pilotis, para instalação de pequenos comércios.

- Cada superquadra, nas Asas Sul e Norte, contará com um único acesso para automóveis e será cercada, em todo o seu perímetro, por uma faixa de vinte metros de largura com densa arborização.

- As superquadras Sul e Norte, nas seqüências de 102 a 116, de 202 a 216 e de 302 a 316, os blocos residenciais terão seis pavimentos, construídos sobre pilotis; nas seqüências de 402 a 416, os blocos terão três pavimentos, sobre pilotis.

- Em todas as superquadras, a taxa máxima de ocupação é de 15\% da área disponível.

- Em todas as superquadras só será permitida a venda dos terrenos dos edifícios, permanecendo de domínio público a área remanescente.

- Na Asa sul os comércios locais correspondentes a cada superquadra deverão sempre ser edificados na situação em que se encontram.

- As entrequadras - áreas situadas entre as superquadras destinam-se a edificações para atividades de uso comum e de âmbito adequado às áreas de vizinhança, como ensino, esporte, recreação e atividades culturais e religiosas.

- O sistema viário que serve as superquadras manterá os acessos existentes nas vias $L-1$ e $W-1$, conforme se verifica na Asa Sul, devendo o mesmo ser obedecido na Asa Norte.

\footnotetext{
${ }^{7}$ Disponível em: <http://www.setur.df.gov.br> , acesso em 12/04/2005
} 
- Nos lagos Sul e Norte só serão admitidas edificações para uso residencial tipo unifamiliar, assim como comércio local e equipamentos de uso comunitário.

- A Plataforma Rodoviária será preservada em sua integridade estrutural e arquitetônica original.

- Será mantido o acesso público à orla do lago Paranoá em todo o seu perímetro, à exceção dos terrenos já registrados em cartório com acesso privativo à água.

\subsection{Alguns números de Brasília}

Brasília localiza-se na região Centro-Oeste, no Distrito Federal. Porém na prática Brasília e o Distrito Federal se confundem, mas há uma diferença entre eles: Brasília seria somente a área que possui o formato de avião, isto é, Asa Sul + Asa Norte + corpo integrado pela Esplanada dos Ministérios e o Eixo Monumental. Contudo, Brasília é apenas mais uma das Regiões Administrativas do Distrito Federal.

O Distrito Federal possui uma área ${ }^{8}$ total de $5.822 \mathrm{~km}^{2}$, sendo formado por 23 Regiões Administrativas, sendo elas:

$\begin{array}{ll}\text { RA I - Brasília } & \text { RA II - Gama } \\ \text { RA III - Taguatinga } & \text { RA IV - Brazlândia } \\ \text { RA V - Sobradinho } & \text { RA VI - Planaltina } \\ \text { RA VII - Paranoá } & \text { RA VIII - Núcleo Bandeirante } \\ \text { RA IX - Ceilândia } & \text { RA X - Guará } \\ \text { RA XI - Cruzeiro } & \text { RA XII - Samambaia } \\ \text { RA XIII - Santa Maria } & \text { RA XIV - São Sebastião } \\ \text { RA XV - Recanto das Emas } & \text { RA XVI - Lago Sul } \\ \text { RA XVII - Riacho Fundo } & \text { RA XVIII - Lago Norte } \\ \text { RA XIX - Candangolândia. } & \text { RA XX - Águas Claras } \\ \text { RA XXI - Riacho Fundo II } & \text { RA XXII - Sudoeste/Octogonal } \\ \text { RA XXIII - Varjão } & \end{array}$

${ }^{8}$ Disponível em < http://www.setur.df.gov.br> . Acesso em 22 out. 2004. 
A população total do Distrito Federal é de 2.189.789 habitantes $^{9}$. A Região Administrativa com maior área é a RA VI - Planaltina -, com $26,5 \%$ da área total do DF, ou 1.534,69 km² e a com menor área é a RA XIX - Candangolândia -, com 0,1\% da área total, isto é, $6,61 \mathrm{~km}^{2}{ }^{10}$ A Região Administrativa mais populosa ${ }^{11}$ é a RA XI - Cruzeiro - e a menos populosa é a RAVII - Paranoá. ${ }^{12}$

O clima do DF é o Tropical de Savana e Temperado Chuvoso de Inverno Seco. Sua temperatura média anual gira em torno de $20,5^{\circ}$ e a umidade relativa do ar varia entre $40 \%$ a $70 \%$. Sua vegetação é o cerrado. ${ }^{13}$

O crescimento demográfico do DF é de aproximadamente $2,82 \%$ ao ano; o Índice de Desenvolvimento Humano (IDH) (0-1) é de 0,844, e o analfabetismo chega a $4,35 \%$ da população. ${ }^{14}$

Seus símbolos são: A Bandeira; O Brasão e Os Hinos (Hino a Brasília e Brasília, Capital da Esperança).

O Distrito Federal é marcado por uma estratificação residencial em que aqueles com maiores poderes aquisitivos se encontram em Brasília (Plano Piloto) e os menos favorecidos nas suas demais regiões administrativas. Segundo Gonzales (1985:88), esta estratificação já era bem marcada desde 1985, época em que a obra foi editada.

A estratificação residencial se expressa na diferença entre os padrões físicos dos setores urbanos, mas ela se constrói e se reproduz através da relação que se estabelece entre os preços dos alojamentos e as rendas das famílias na evolução da cidade. De maneira geral, a medida da renda média familiar tem aumentado no Plano Piloto ${ }^{15}$, distanciando-o cada vez mais das outras localidades urbanas do Distrito Federal. O número de famílias com rendas inferiores a três salários mínimos é cada vez mais reduzido no Plano Piloto, em função da elevação dos preços da habitação nesta localidade.

Contudo, é importante destacar o que está disponibilizado no site da Secretaria de Turismo do Distrito Federal (Setur) ${ }^{16}$ :

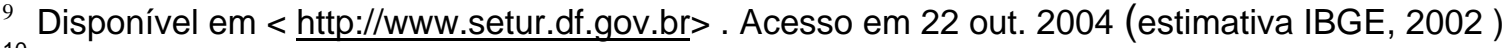

10 Idem

${ }^{11}$ Relação feita por cálculo de habitantes $/ \mathrm{km}^{2}$

12 Disponível em < http://www.setur.df.gov.br> . Acesso em 22 out. 2004

13 Idem

${ }^{14}$ Idem

${ }^{15}$ Mesmo que Brasília.

${ }^{16}$ Disponível em http://www.setur.df.gov.br/003/00301015.asp?ttCD_CHAVE=8619, acesso em 12/04/2005.
} 
Brasília possui a renda per capita mais elevada do País. No ranking de produção de riquezas dos Estados, possui o nono maior PIB. Um estudo realizado recentemente pela ONU sobre o Índice de Desenvolvimento Humano, o IDH, concluiu que o bairro do Lago Sul é o melhor lugar do mundo para se viver, com privilegiados $28 \mathrm{mil}$ moradores. Obteve o índice de 0,945 (quanto mais próximo de 1 melhor o nível de vida), ficando na frente de potências como Canadá, Austrália e Estados Unidos. As cidades-satélites mais pobres do Distrito Federal, Planaltina e Brazlândia, obtiveram índices acima da média brasileira e bem à frente de Estados como Ceará, Tocantins e Amazonas. Ou seja, mesmo para os mais pobres, a vida pode ser melhor em Brasília do que nas demais regiões.

\subsection{Turismo em Brasília}

Devido ao fato de Brasília estar diretamente ligada à representatividade do Poder Nacional, como se percebe logo abaixo, a maior parte dos atrativos turísticos que são divulgados ${ }^{17}$ gratuitamente pelo governo para os turistas são representados por aqueles que estão localizados no centro da cidade e, na sua grande maioria, são locais que representam poder em nossa sociedade, tais como os três poderes da república: Poder Executivo, Poder Legislativo e Poder Judiciário, além do poder religioso, o poder da mídia e o intelectual-cultural ${ }^{18}$.

Os principais pontos turísticos do centro de Brasília $^{19}$ são:

I. Localizados no Eixo Monumental: Catedral Santa Maria dos Militares Rainha da Paz, Memorial JK, Memorial dos Povos Indígenas, Palácio do Buriti, Centro de Convenções Ulysses Guimarães, Planetário (atualmente fechado para reforma), Torre de Televisão, Museu Nacional de Gemas, Teatro Nacional Cláudio Santoro, Museu da Caixa Econômica Federal, Museu Brasileiro de Contabilidade.

II. Localizados na Esplanada dos Ministérios: Catedral Metropolitana Nossa Senhora Aparecida, Museu do Trabalho, Museu da Fundação Nacional de Saúde,

\footnotetext{
${ }^{17}$ Distribuição de folders, revistas, mapas em centro de atendimento ao turista e hotéis da cidade.

${ }_{10}^{18}$ Representado, nesse caso, pelos museus.

19 Informação retiradas de: Brasília de asas abertas pra você. ADETUR-DF(atualmente SETUR). GDF. UNESCO.
} 
Palácio do Itamaraty (Ministério das Relações Exteriores), Palácio da Justiça (Ministério da Justiça), Congresso Nacional (museu: Senado e Câmara), Espaço Lúcio Costa, Museu Histórico de Brasília, Palácio do Planalto, Supremo Tribunal Federal, Praça dos Três Poderes, Pavilhão Nacional (mastro da Bandeira Nacional), Panteão da Pátria, Espaço Oscar Niemeyer.

\section{CONCEITUANDO TEMPO LIVRE, LAZER E ÓCIO}

O termo "lazer" foi instituído pelo capitalismo industrial a partir do século XVIII na Europa, do século XIX no Estados Unidos da América e início do século XX no Brasil. Antes disso, nas sociedades feudais e mesmo nas sociedades précapitalistas $^{20}$ não havia uma distinção clara entre tempo para o trabalho e o tempo para outras atividades. Como afirma Sant'anna (1994:14):

isso porque, nas sociedades predominantemente rurais, a tendência é a de vivenciar e entender a diversão, o descanso, o convívio social, familiar e o trabalho, como esferas e tempos que se misturam e se confundem. Em certas zonas rurais da Inglaterra pré-industrial, Thompson $^{21}$ aponta a dificuldade existente em se proceder a uma divisão rígida entre trabalho e diversão, trabalho com a própria vida e a gama variada de atividades nela presentes.

As relações sociais eram marcadas pelo trabalho coletivo, "juntavam-se muitos para o trabalho, encerrando-se estes com bailes e cantorias. Ou seja, tanto para os trabalhos da agricultura, quanto para a manufatura doméstica, reuniam-se

\footnotetext{
${ }^{20}$ Período da economia mercantil, séculos XII a XV, em que a produção se destina a trocas e não apenas a uso imediato. Não havia trabalho assalariado, os trabalhadores eram servos e vendiam o produto do seu trabalho, mas não o seu trabalho.

${ }^{21}$ Cf. THOMPSON, Edward P. (1979). Tiempo, diciplina de trabajo y capitalismo industrial.
} 
os vizinhos, agregando-se trabalho e festa" (SIQUEIRA, 2004:31).O tempo era ordenado pelo ritmo da natureza.

O trabalho inscreve-se nos ciclos naturais das estações e dos dias: é intenso durante a boa estação, e esmorece durante a estação má. Seu ritmo é natural, ele é cortado por pausas, cantos, jogos, cerimônias. Em geral se confunde com atividades do dia: da aurora ao pôr-do-sol. Entre trabalho e repouso o corte não é nítido (DUMAZEDIER, 1974:26).

As principais características do feudalismo eram:

- produções de subsistência, auto suficientes, destinadas fundamentalmente ao consumo e não à troca, como podemos notar no trecho a seguir: "produzia-se para viver e não para acumular ou ter um excedente." (SIQUEIRA, 2004:31).

- o trabalho era visto como uma atividade de menor valor ou como uma punição - o que remete à própria origem da palavra trabalho, em latim tripalium, que era um instrumento com três pontas que servia tanto para colher o trigo quanto para realizar torturas. Quem trabalhava eram os escravos, enquanto os aristocratas exerciam o ócio. Segundo Siqueira (2004:30), "é bastante comum encontrar-se referências no sentido de que já na Grécia antiga o trabalho ligado à sobrevivência (doméstico, agrícola) era representado como um castigo imposto e, portanto, delegado aos escravos $e$ aos desafortunados". Castro (2002:95) também confirma essa afirmação em um trecho de sua obra onde diz: "inicialmente, o trabalho era visto como um castigo divino."

Com o surgimento do capitalismo, durante o Renascimento e com a reforma protestante protagonizada por Lutero, o trabalho passa a ter um outro significado e torna-se uma atividade digna e virtuosa. Surgem as relações assalariadas de produção e o tempo passa a ser controlado pelo relógio. Nas palavras de Sant'ana (1994:14): "o relógio da natureza é substituído pelo relógio mecânico e por maneiras diferentes de conceber o tempo e as atividades humanas". E com isso o tempo passou a ser cronometrado e dividido em tempo livre e tempo de trabalho, transformando-se em um produto, pois passa a ter um valor. Segundo Sant'ana (1994:15), "[...] o tempo passou a ser comprado, vendido e negociado de múltiplas 
formas, tal qual uma mercadoria [...] por isso perder qualquer quantia de cada um deles significa um risco à sobrevivência humana."

A produção de bens passa a ser acumulativa e, por isso, no início do capitalismo, trabalhava-se de segunda a domingo com uma jornada diária de 16 horas. De acordo com Camargo (2003:39), "iniciava-se o trabalho aos dez anos e trabalhava-se até a morte, geralmente prematura", sempre com o objetivo de se produzir mais para o capitalista.

Houve lutas contra esse sistema de trabalho, porém, eram reprimidas pelos órgãos policiais e somente em meados do século XIX, na Europa, com 0 desenvolvimento das indústrias, é que os primeiros resultados foram obtidos (CAMARGO, 2003), à custa de muito sangue derramado. Além do desenvolvimento da industrialização, notou-se que para se produzir mais era necessário um tempo para o homem descansar, além do fato das pessoas precisarem de um tempo para poder consumir o que se produzia.

Paralelamente, ao desenvolver-se em escala mundial, o sistema capitalista encontrou no tempo livre novos alicerces para o aumento da produtividade. A necessidade de descanso, inerente ao corpo humano, começa a ser reconhecida por algumas empresas, na medida em que o corpo descansado demonstra ser mais produtivo durante o trabalho. Além disso, outros fatores estão em jogo, como o desenvolvimento da indústria do lazer, o crescimento da produção e do consumo em massa de brinquedos, equipamentos esportivos, atividades e eventos lúdicos mais modernos, implantados no decorrer deste século e que demandam a existência de um tempo livre e disponibilidade financeira ${ }^{22}$ de grande parte da população (SANT'ANNA, 1994:19).

Atualmente, apesar do processo de transformações impostas pelo novo mundo do trabalho - em que prevalece a reestruturação produtiva, a terceirização e o aumento crescente do desemprego estrutural, dentre outros fatores - a maioria das jornadas de trabalho ainda é, prioritariamente, de oito horas diárias e de 44 horas semanais, ou seja, trabalha-se cinco dias e meio da semana e folga-se um dia e meio, além do direito a férias anuais remuneradas, feriados, décimo terceiro salário. Diante a consolidação dos direitos trabalhistas, conquistados em dois séculos de

${ }^{22}$ Como podemos notar na citação acima, deste o inicio da criação do tempo livre nota-se a existência da exclusão, visto que o tempo livre era para aqueles que possuíam disponibilidade financeira. 
lutas, o homem passou a ter não somente tempo para o trabalho, mas também, tempo livre, mudando, assim, a concepção de tempo.

Com a criação do tempo livre, surge o lazer que, no seu sentido mais amplo, quer dizer um conjunto de atividades realizadas no tempo livre em contraposição ao trabalho.

De forma geral, as pessoas, sobretudo aquelas que trabalham fora ou estudam, sonham com a chegada do tempo livre para realizar atividades de livre escolha - o lazer, ou para reservar um tempo à contemplação ao não fazer nada, ao dolce farniente - o ócio (PADILHA, 2002:125).

\subsection{Tempo Livre}

Para Waichman (2003:35), "a diminuição do horário de trabalho gera um vazio, que é conhecido como tempo liberado e não tempo livre, pois é apenas um espaço temporal disponível, um resíduo". Nesse contexto, entende-se tempo livre como tempo oposto ao tempo de trabalho. "De Grazia demonstra como do século XVII ao XIX se desenvolveu um novo conceito de tempo por todo o mundo industrial, numa nova concepção de trabalho" (BRUHNS, 2002:25), reduzindo-se o tempo de trabalho e criando-se o tempo "livre", tempo que é controlado pelo relógio, porém, um tempo no qual se teria mais possibilidades de fazer escolhas do que quando se tem que cumprir com suas obrigações.

O conceito de tempo livre que utilizarei a seguir é o de um tempo livre de "obrigações", que é diferente de um tempo livre para a "liberdade", uma vez que se entende obrigações como sendo atividades impostas ao indivíduo e liberdade como uma utopia, pois seria uma ousadia dizer que alguém é totalmente livre para fazer suas escolhas, visto que a cultura, a sociedade, a política e a economia influenciam de certa forma nessas escolhas. Por isso, concordo com Padilha quando usa a expressão "tempo livre" entre aspas.

Além disso, o tempo livre terá um enfoque em suas três potencialidades que, de acordo com Mantero (2000:186-187), são: 
O tempo livre envolve três potencialidades ou funções: descanso, lazer e criação, momentos diferenciados de forma qualitativa em nossa sociedade e que exprimem de três maneiras: como um descanso forçado, como um lazer programado e como uma criação regulada.

O descanso forçado é para os que trabalham um meio de recuperarse do cansaço e para as pessoas desocupadas e lou desempregadas um placebo que as induz à inação, propiciandoIhes, dessa maneira, a alternativa de uma distração relaxante, para evitar que se preocupem com sua real situação.

No caso do lazer programado, a sociedade tenta reanimar a entediada vida urbana desagregada com atividades baseadas sobretudo em um entretenimento trivial - a assistência a uma televisão estereotipada - para compensar a difusão social ocasionada pela falta de opções de lazer espontâneo como a possibilidade do jogo ou de uma atividade de expressão.

Por último, a criação, provavelmente a mais fundamental das três instâncias, alimenta na sociedade o processo civilizatório que faz perdurar na cidade estilos de vida e diferenças mediante canais institucionalizados e se anula quando é regulada pelas expectativas da sociedade. Só na criação livre as pessoas expressam a criatividade, gerando a possibilidade de uma transformação da sociedade. Há, pois, um território a ser conquistado pelo uso do tempo livre qualitativo.

\section{2 Ócio}

A noção de lazer (enquanto ócio) vem do latim licere (o que é lícito, o que é permitido). Portanto, ócio significava, como sugere Waichman (2003:44):

ter tempo para fazer o que nós bem entendermos, implica uma qualidade subjetiva em que o importante não é o tempo nem a atividade, mas a disposição. No entanto, devemos considerar que essa disposição também é condicionada socialmente.

No grego, scolé (enquanto ócio) opõe-se a ascolé (estado de servidão). De Scolé deriva a palavra escola. De acordo com Waichman (2004:44):

Scolé era o desenvolvimento dos valores supremos da cultura grega, que permitiam a contemplação da sabedoria. $E$ a isso só podiam chegar àqueles que pertenciam às camadas superiores da sociedade. Tinham tempo para isso àqueles que, com o trabalho dos escravos, possuíam a riqueza material possibilitadora de um tempo para o ócio. E esse tempo livre era, justamente, o oposto do tempo para não fazer nada. Era o tempo do saber não utilitário. 
Como podemos notar, em algumas sociedades mais antigas, o ócio representava uma virtude, digna de poucos. Bacal ${ }^{23}$ (apud SANT'ANNA,1994: 20, nota 27) diz que "para Aristóteles, por exemplo, o ócio era o princípio do Universo e em um estado de alma em que o cidadão grego podia conhecer a verdade." Afirmava-se, ainda, de acordo com Waichman (2003:44) que "o não-ocioso era aquele que trabalhava, portanto, não podia alcançar os verdadeiros valores da verdade, da beleza e da bondade. O ócio é um ideal de vida, portanto, um fim; ao passo que o trabalho que o possibilita, é um meio ."

Já para os romanos, otium referia-se a um tempo de não-trabalho posterior ao nec-otium, a negação do ócio, que era um tempo destinado a atividades produtivas, Waichman (2003:45) complementa:

Aqui, o ócio não implica um estatuto social, um modo de vida, mas parte do tempo cotidiano oposto ao das obrigações. Já o ócio é um meio, não um fim. Surgem os ócios massivos como parte da dominação, do divertimento imposto pelos poderosos para entreter os desocupados.

Atualmente, em sociedades capitalistas, o conceito de ócio não possui mais o mesmo significado de antes, passando a ser visto como algo que deve ser combatido, haja vista o prejuízo ao sistema capitalista.

Desde o século passado ${ }^{24}$, em nome da boa ordem e dos padrões de decência, tem-se a instituição do ócio como coisa imoral, indigna e, portanto, objeto de tratamento e de sanções normalizadoras, e a recorrente necessidade de providências que deveriam ser tomadas em nome de tal ameaça (SANT'ANNA, 1994:21, grifos da autora).

Complementando, Sant'ana (1994:20) diz:

Se em momentos e sociedades mais antigas, já se atribuiu um sentido nobilitante e positivo ao ócio, contrariamente, em nossos dias, é mais comum entendê-lo como sinônimo de vadiagem, preguiça, inutilidade, tédio, improdutividade, imoralidade e até mesmo doença.

Neste contexto, o lazer surge como a "cura" do ócio:

\footnotetext{
${ }^{23}$ Cf. BACAL, Sarah S. (1978). Realidade e uso do tempo livre. p.23

${ }^{24}$ Século XIX
} 
Melhor ainda, determinadas práticas sociais foram denominadas ócio e este foi tomado como um problema carente por soluções a serem produzidas pela administração pública e empresas particulares. Soluções que podem estar tanto nas técnicas de disciplina do trabalho como naquelas de organização dos usos do tempo livre. Neste último caso, estamos tratando com a produção institucional de formas de diversão, de descanso, cultura e evasão, que, ao mesmo tempo em que instituem uma distinção entre práticas ociosas - negativas - em nome de práticas de lazer, procedem à criação do ócio como erro a ser corrigido pelos programas de lazer (SANT'ANA, 1994:20-21).

Enfatizando essa idéia, Siqueira (2004:37) diz:

Se as atividades de lazer são, em princípio higiênicas, salutares, o ócio vai sendo cada vez mais associado à preguiça, à imoralidade, à improdutividade, ao vício. As primeiras podem "corrigir" o segundo. E a confirmação desta tendência é a "novíssima" proposição de alguns autores, na atualidade, em torno do "ócio produtivo".

E o termo ócio vai sendo substituído pelo termo lazer:

Assim sendo, com o desenvolvimento do capitalismo, assiste-se à passagem do "ócio", nada fazer, este estar contemplativo por excelência, bastante valorizado nas culturas orientais, ao "lazer": ocupação, com atividades, do tempo livre (SIQUEIRA, 2004:36).

\subsection{Lazer}

De acordo com Dumazedier (1974), existem quatro tipos de definições referentes ao lazer, sendo elas:

a) a primeira, para D. Rieman, H. Wilensky e M. Kaplan ${ }^{25}$, o lazer é visto como um estilo de comportamento, onde toda atividade pode ser considerada um lazer: trabalhar com música, lavar louça ouvindo rádio, misturar o erotismo ao sagrado, etc. Porém, esta definição é mais psicológica do que socióloga e confunde lazer e prazer, lazer e jogo, não permitindo que se defina um campo específico entre as diversas atividades que assumem diferentes funções na sociedade;

\footnotetext{
${ }^{25}$ Pelo menos em seus escritos anteriores a 1973.
} 
b) a segunda definição situa o lazer como sendo apenas aquilo que é oposto ao trabalho profissional, ignorando a existência de obrigações doméstico-familiares;

c) a terceira exclui do lazer as obrigações doméstico-familiares, mas inclui as obrigações sócio-espirituais e sócio-políticas como lazeres, porém, este tipo de atividades ao mesmo tempo que podem trazer ao indivíduo uma satisfação profunda, pode, também, exigir uma disciplina e até mesmo um sacrifício penoso. Seja como for, vale ressaltar que se trata de uma exigência institucional da sociedade e não do indivíduo;

d) a quarta trata do lazer como um tempo destinado ao indivíduo para que ele possa fazer suas escolhas livres das obrigações do trabalho, familiares, sócioespirituais, tornando-se possível a liberação das obrigações sócio-políticas.

A idéia sobre lazer que serve de base para as reflexões aqui desenvolvidas é associada à quarta definição de Dumazedier, entendendo como tempo para o lazer aquele que o indivíduo possui após ter realizado suas atividades obrigatórias. Eker ${ }^{26}$ (apud VIEITEZ, 2002:128) afirma que lazer "é a porção de tempo não dedicada ao trabalho, que fica para a pessoa depois que ela realizou as atividades nãoprodutivas essenciais, como ir e vir do trabalho, comer, dormir e outras formas de atividades privadas."

O descanso como mero ócio, como simples nada fazer, faz parte do modo pelo qual os homens utilizam o seu tempo livre. Mas não é ele que define o lazer. O que define o lazer é a capacidade especificamente humana de transformar descanso em lazer, de utilizar o tempo livre para a realização de atividades que dêem satisfação e prazer, e ao mesmo tempo contribuam para o desenvolvimento dos indivíduos e da sociedade. De acordo com essa acepção Marx e Engels distinguem entre atividades de lazer positivas e negativas. As atividades de lazer positivas são aquelas que contribuem para o desenvolvimento das pessoas, como, por exemplo, estudar, ler livros, ouvir músicas, participar de jogos e atividades sociais e tantas outras. Atividades de lazer negativas são aquelas que seriam prejudiciais à pessoa, física e mentalmente, e que, portanto, podem ser danosas ao desenvolvimento da sociedade. Encontram-se entre elas o alcoolismo, as várias formas de prostituição e outras (VIEITEZ 2002:129).

O lazer passa a ser visto como atividades, que devem ser preferencialmente, positivas ao desenvolvimento da sociedade, fazendo com que o "lazer negativo" seja considerado como ócio. Assim,

${ }^{26}$ Cf. EKER, Glen (1991). Leisure and lifestyle in selected writings of Karl Marx. 
lazer: incluiria todas as atividades ou ocupações que as pessoas podem desenvolver ou se dedicar, depois de terem se desobrigado das tarefas (familiares, profissionais e sociais). E enquanto lazer, as atividades do tempo livre podem ser melhor controladas, diminuindo seu caráter de desconhecido, eventualmente imoral e perigoso. Trata-se de "atividades", categoria distinta da de ócio (nada fazer, percebida e desconsiderada, crescentemente como "vagabundagem") (SIQUEIRA, 2004:35).

O lazer sendo benéfico para o desenvolvimento da sociedade, passa a ter outras funções, tornando-se mais um produto do sistema capitalista.

[...] Mercadorias, que possam realizar o capital investido por alguém. Afinal, se está no tempo da produção e da produtividade. $O$ livre-pensar, a reflexão, a contemplação, o ócio e outras possibilidades infinitas de se construir o tempo têm que ser construídas como "atividades de lazer". Atividades que, simultaneamente, gerem, por sua vez, empregos, lucros, dinamização da economia para os segmentos envolvidos em criar (SIQUEIRA,2004:37).

Ao transformar o lazer em mercadoria, surge então a exclusão, visto que só terão acesso ao lazer aqueles que tiverem condições econômicas para pagar por ele. Assim, ressalto Padilha (2000:68) ao afirmar que:

[...] o lazer, tal como se apresenta hoje, é uma atividade (ou um conjunto de atividades) de consumo. Essa afirmação compreende alguns pontos que poderiam ser assim resumidos:

$1^{\circ}$. se as atividades de lazer são transformadas em mercadorias a serem consumidas, o lazer está perfeitamente integrado ao sistema econômico do qual ele faz parte;

$2^{\circ}$. Se este sistema econômico tem o consumo de mercadorias como pilar de sustentação, e momento de realização do lucro não só as atividades de lazer se tornam mercadorias, como o próprio tempo de lazer se configura em tempo para consumir mercadorias e,

$3^{\circ}$. Se é real a tendência de aumento do tempo livre em função das transformações tecnológicas, parece provável que aumentará consideravelmente o numero de serviços especializados em entretenimentos (viagens, recreações, lazer).

Contudo, o lazer passa então a ser símbolo de status. "Nesse caso, focalizase o fato de que as pessoas usam as mercadorias de forma a criar vínculos ou estabelecer distinções sociais" (FEATHERSTONE, 1995:31). 
Outra função do lazer é a de preparar o trabalhador para o trabalho, ou seja descansá-lo, distraí-lo, etc. Isso ocorre pois, desde o início da Revolução Industrial, houve uma separação do trabalho com o lúdico e o sagrado, conforme apresentado no início deste capítulo. "Em meios às máquinas, o trabalho dividido por tarefas, setores de produção e medido em horas, em unidades gastas de energia, não admite ser permeado por momentos ou atitudes de diversão e descanso" (SANT'ANA, 1994:17).

\subsection{Abordagens teóricas do lazer}

Diante desta diversidade de funções que são atribuídas ao lazer criaram-se duas abordagens sobre o tema: a funcionalista e a marxista.

De acordo com Padilha (2004:slides 5-10) a abordagem funcionalista é a romântica; moralista; compensatória; e utilitarista.

A abordagem romântica é marcada pela ênfase nos valores da sociedade tradicional e pela nostalgia do passado [...].

[...] a abordagem moralista é motivada pelo caráter de ambigüidade do lazer e reforça determinados valores morais[...].

[...] a abordagem compensatória enfoca o lazer em oposição ao trabalho - visto como alienado, mecânico, fragmentado e especializado. O lazer compensaria a insatisfação e a alienação do trabalho.

[...] a abordagem utilitarista reduz o lazer à função de recuperação da força de trabalho ou à sua utilização como instrumento de desenvolvimento. Ressalta os ganhos para os empregados pelos resultados psicológicos que dão retorno às empresas[...].

É a abordagem mais utilizada ao se definir o lazer, e concordo com Padilha (2000:60) ao dizer que se deve:

[...]salientar que muitas concepções de lazer e de tempo livre acabam sendo conservadoras na medida em que pensam a sociedade como homogênea, equilibrada, sem contradições, na qual o lazer é supostamente divertimento para todos. A maioria dessas concepções são funcionalistas pois pensam no lazer como o tempo necessário para a atividade ou o descanso que visem prioritariamente a compensação do trabalhador para que ele possa voltar novamente ao trabalho um pouco mais recuperado. 
Mais do que a compensação do trabalho, o lazer nessa abordagem nos aparece como sendo algo mágico, capaz de resolver os problemas da vida, e é nesse contexto que entra um questionamento que Padilha (2000:60) faz ao dizer que:

não se coloca o porquê da necessidade de se compensar algo que se perde... Se a realidade revela a prevalência de um tempo livre funcionalista, em que as atividades de lazer visam apenas uma "manutenção" do ser humano, não existe espaço para um tempo livre "crítico" do qual pode emergir questionamentos e mudanças na sociedade?

Por outro lado, surge a abordagem marxista como crítica ao funcionalismo, que "compreende a sociedade de forma diferente, pois no lugar do equilíbrio e da harmonia enxerga conflitos e contradições" (PADILHA, 2004:slide 31) e "nesta perspectiva, nem todo trabalho é necessariamente ruim e nem todo lazer é necessariamente bom, pois o lazer não é visto como uma salvação para todos os males sociais - o trabalho à frente." (PADILHA, 2004:slide 36). Nessa abordagem, o que se leva em consideração é que a sociedade é dividida em classes sociais distintas, e que o lazer também passa a ser distinto para estas classes, como podemos notar no texto de Padilha (2004, slide 37): “a sociedade é formada por

classes sociais distintas cujas condições materiais de existência determinam o acesso e o conteúdo de lazer de cada classe".

\section{APONTAMENTOS TEÓRICOS SOBRE ELITE}

O termo elite deriva do latim eligere, que significa, em português, escolher. Trata-se de grupos de pessoas que ocupam lugares de destaque em sua sociedade, como por exemplo, governantes, rainhas da beleza, intelectuais, ministros, artistas, 
socialites. Porém, como existem diversos tipos de elites, há também uma hierarquia entre elas, em que algumas elites são mais elites que outras, fato que é decidido de acordo com o poder que a elite possui diante a sociedade.

Segundo Silva (1986:389), elite é definida como sendo:

um grupo de pessoas que, numa sociedade qualquer, ocupam posições eminentes. Mais especificamente, designa um grupo de pessoas eminentes num determinado campo - principalmente a minoria governante e os círculos onde é recrutada.

Mas, este termo não teve sempre este significado. Na França da Idade Média, elite significava "a nata ou a flor" dos produtos oferecidos para venda, isso é, eram conhecidas como elite as melhores mercadorias. Posteriormente, por volta do século XVIII, o uso desse termo se ampliou e passou a ser utilizado como distinção, não somente de bens e produtos, mas para diferenciar algumas pessoas ou grupos. Além disso, também passou a ser utilizado em outras línguas, além do francês (SILVA,1986).

Com o passar do tempo, esse termo foi ganhando novos significados. As transformações históricas ocorridas entre os séculos XVIII e XIX foram responsáveis por isso, segundo Martinez (1933). Dentre elas, o autor destaca:

a independência das treze colônias inglesas na América do Norte, que se constituíram nos Estados Unidos da América e abraçaram o regime republicano federativo, inteiramente diverso do modelo monárquico absolutista adotado até então nas principais nações européias; a Revolução Francesa de 1789, que reduziu os poderes da monarquia, nobreza e clero, abrindo espaço para a ascensão ao poder de uma nova classe, a burguesia capitalista; a Revolução Industrial, que modificou inteiramente a vida econômica e social, em primeiro lugar dos mais influentes países da época, e, a seguir, do mundo inteiro (MARTINEZ, 1933:7).

Elite, na atualidade, é entendida como aqueles que dispõem de maior acesso aos valores dominantes e ao seu controle; é composta pelas pessoas que ocupam as mais altas posições numa determinada sociedade. A elite pode ser formada por pessoas que ocupam cargos no poder político, que possuem riqueza, respeitabilidade ou conhecimentos. Nesta monografia, o universo de pesquisa é apenas a elite intelectual de Brasília, mais especificamente a elite formada por 
pessoas que possuem determinados conhecimentos desenvolvidos e difundidos na universidade.

Alguns outros termos constantemente são confundidos com elite, como casta dirigente, aristocracia, estamento, primeira classe política e classe dirigente. Isso ocorre devido ao fato do termo elite ter sido uma reformulação dessas instituições. Como Schümpeter ${ }^{27}$, citado por Keller (1967:38), nos fez ver, "cada situação social é a herança de situações anteriores, das quais retira suas culturas, disposições e espírito, como também elementos de sua estrutura social e concentração de poder."

Complementando, Keller (1967:38) afirma que "como o passado está sempre conosco, enriquecendo o presente e com ele se confundindo, é de se esperar que as elites reflitam suas afinidades históricas com esses grupos."

Contudo, pode-se afirmar que as elites seriam a evolução das classes e castas dirigentes, como sugere o autor:

\begin{abstract}
Assim, para examinarmos as origens das elites estratégicas, somos compelidos a descer às origens das classes sociais com as quais essas elites estão, naturalmente e com freqüência, interligadas. Uma observação mais cuidadosa indica que as elites estratégicas são uma cristalização, um desdobramento de classes dirigentes. Devem, pois, ser consideradas não como equivalentes funcionais, mas sim como alternativas estruturais de classes e castas dirigentes, representando uma forma de liderança social mais especializada e adiantada (KELLER, 1967:38).
\end{abstract}

A casta dirigente é uma camada superior cuja atribuição é o exercício de tarefas sociais, consideradas por seus membros importante. Seu recrutamento é feito com base em origens biológicas, isso é, de forma hereditária, em que seus membros pertencem à mesma raça, etnia, profissão ou religião. Nela se entra por "condições de berço" e só se sai com a morte. É formada com base em religião, parentesco, idioma, domicílio territorial, padrão econômico e atividades ocupacionais (DICIONÁRIO DE SOCIOLOGIA,1961; KELLER,1967).

A aristocracia é uma "sociedade politicamente organizada, cujo controle estatal é monopolizado por uma camada social privilegiada (DICIONÁRIO DE SOCIOLOGIA,1961:32)" e se "compõe de famílias ligadas por laços de parentesco e de riqueza. [...] são mais abertas do que as castas; porém, ocupacionalmente, menos especializadas" (KELLER,1967:39). Algumas características são o

${ }^{27}$ Cf. SCHUMPETER, Joseph Alois (1955). Imperialism and social class. p. 111 
nativismo ${ }^{28}$ e um código especial de honra, etiqueta e convenção, que servem para manter as barreira sociais tornando as aristocracias uma minoria que se destaca do restante da população (DICIONÁRIO DE SOCIOLOGIA,1961; KELLER,1967).

O estamento é uma camada social semelhante a casta, porém é mais aberta e não é ritualizado como a casta. De acordo com o Dicionário de Sociologia (1961:122), o estamento permite "contatos físicos com membros de outros estamentos não poluem o indivíduo e não envolvem a necessidade de ritos expiatórios." Outra característica é a presença de um conceito específico de honra. "Esse conceito determina não somente o modo de viver materialmente, mas também a admissibilidade de certas atividades, assim como a maneira de exercêlas"(DICIONÁRIO DE SOCIOLOGIA,1961:122).

A primeira classe política refere-se a uma camada superior em uma sociedade politicamente centralizada, seu acesso se dá não somente a condições de berço, mas também a feitos realizados, ligações matrimoniais e conquista de honrarias, podendo sua posição ser adquirida ou perdida (KELLER,1967).

Freqüentemente fonte de confusão tem sido considerar indiferente classe política e elite, visto que a classe política é um dos grupos pertencentes a elite. Para Martinez (1933:11) a diferença entre elite e classe política se dá da seguinte forma:

classe política é um conceito que explica o posicionamento dos indivíduos do ponto de vista da cultura, do direito, das instituições e da política; elite é um conceito que se refere ao posicionamento dos indivíduos no contexto econômico e social.

As classes dirigentes são formadas pelas altas classes sociais, basicamente por aqueles que possuem maior poder aquisitivo de uma sociedade. Assim como ocorre com a primeira classe política, ocorre com as classes sociais, visto que é comum confundir as altas classes sociais com elite. Keller (1967:42-3) afirma que:

embora uns tenham relação com os outros, não são, de maneira alguma, idênticos. A origem das elites estratégicas (como de todos os tipos de grupos dirigentes) reside na heterogeneidade da comunidade - quanto a idade, sexo, condições étnicas, habilidades, e coisas semelhantes. A origem das classes sociais está na divisão social do trabalho.

\footnotetext{
${ }^{28}$ Direitos conferidos por nascimento.
} 
Contudo, as classes dirigentes são uma forma de liderança social, que consiste de uma única camada superior responsável por várias funções sociais chaves. Seu acesso pode se dar pela hereditariedade, mas seu fator decisivo é a abastança e a riqueza. Seu poder principal é o econômico e não o político (KELLER,1967). No entanto, quanto a essa afirmação, conforme ensina Marx, no conjunto de suas obras, é impossível considerar a esfera econômica separada da política, uma vez que:

As idéias da classe dominante são, em cada época, as idéias dominantes; isto é, a classe que é a força material dominante da sociedade é, ao mesmo tempo, sua força espiritual dominante. [...] Os indivíduos que constituem a classe dominante possuem, entre outras coisas, também consciência e, por isso, pensam; na medida em que dominam como classe e determinam todo o âmbito de uma época histórica, é evidente que o façam em toda a sua extensão e, conseqüentemente, entre outras coisas, dominem também como pensadores, como produtores de idéias; que regulem a produção e a distribuição das idéias de seu tempo e que suas idéias sejam, por isso mesmo, as idéias dominantes da época (MARX \& ENGELS,1989:72).

Keller (1967:69) fez um quadro de diferenciação entre classes dirigentes e elites estratégicas, apresentado a seguir:

\begin{tabular}{|c|c|c|}
\hline $\begin{array}{c}\text { Critérios de } \\
\text { comparação }\end{array}$ & $\begin{array}{c}\text { Classe } \\
\text { dirigente }\end{array}$ & $\begin{array}{c}\text { Elites } \\
\text { estratégicas }\end{array}$ \\
\hline Número & Uma & Várias \\
\hline Tamanho & Grande & $\begin{array}{c}\text { Pequenas, } \\
\text { concentradas }\end{array}$ \\
\hline Duração & Vida longa & Curta \\
\hline Modo de ingresso & Berço e riqueza & $\begin{array}{c}\text { Capacidade } \\
\text { especializada }\end{array}$ \\
\hline Modo de saída & Perda da & Incompetência \\
\hline Aiqueza & Difusa e ampla de autoridade & Especial e limitada \\
\hline Laços culturais & Instrução, & Sem \\
& educação & especificação \\
\hline Acessibilidade & Relativamente & Relativamente \\
& fechada & aberta \\
\hline
\end{tabular}


O mesmo autor ainda afirma que:

em síntese, o aparecimento e a organização das elites estratégicas guardam relação, mas não identidade, com o aparecimento e a organização das classes sociais. Sua inter-relação gera permanente confusão porque, historicamente, as elites estratégicas eram muitas vezes recrutadas de uma ou outra classe social cuja posição no quadro geral da sociedade era alta. Em vista de sua vinculação com os valores centrais do sistema social, as elites estratégicas ocuparam um alto status social, independentemente da riqueza material ou das legítimas conquistas de seus membros. Como muitas vezes eram recrutadas da classe superior, esses dois tipos de posição facilmente foram confundidos e considerados indiferentes (KELLER,1967:69).

Ainda de acordo com Keller (1967:31), "certas elites podem despertar atenção momentânea, mas somente certos grupos de liderança exercem impacto social geral e duradouro".Esse grupo de elites, "cujos julgamentos, decisões e atos têm importantes conseqüências para muitos membros da sociedade" (KELLER, 1967:31), o autor define como elites estratégicas, fazendo parte desse grupo os líderes políticos, econômicos, militares, morais, culturais e científico.

As elites estratégicas, a nosso ver, consistem naquela minoria de indivíduos que têm a responsabilidade de manter em perfeitas condições de funcionamento a sociedade, como sistema organizado que é, de maneira a poder enfrentar e superar as perenes crises coletivas que ocorrem. Essa minoria pode ocupar posições sociais específicas pode concentrar-se em um ou vários pontos, pode ter uma atuação satisfatória, deficiente ou excelente; seja como for, as elites estratégicas existem e permanecem, porque têm funções sociais precípuas a exercer, e só por isso. Esta minoria de indivíduos de escol, além disso, distingue-se pelo fato de ser comumente encarada não quanto à importância dos seus membros, mas sim quanto às suas missões (KELLER,1967:35).

\subsection{Teoria das elites}

Em meados do século XIX, alguns filósofos e sociólogos (da recém-nascida sociologia) começam a preocupar-se com o aumento das desigualdades sociais 
geradas no seio da chamada Revolução Industrial. Destacou-se a proposta socialista do alemão Karl Marx, como crítica das desigualdades e injustiças sociais. Sua teoria de classes sociais antagônicas e da necessidade de romper com o sistema capitalista para acabar com a propriedade privada e as diferenças econômicas e sociais radicais entre as classes gerou alguns movimentos, lutas e organizações sociais importantes do século XIX.

Mas, suas teorias que mostravam que a desigualdade social não era algo natural do ser humano e sim conseqüência da organização sócio-econômica não foram aceitas incondicionalmente por todos. Muitos pensadores continuavam defendendo a idéia de que a desigualdade entre as pessoas tem sua causa nas próprias pessoas. Dentre estes estudiosos, destacam-se - segundo Martinez (1933:8) - Gaeteno Mosca (1858-1941) que:

desenvolveu a doutrina da classe política e em seguida aperfeiçoou-a com a teoria da classe dirigente, mais abrangente do que a primeira, na qual se abrigaria o que naquela época se denominava alta sociedade ou alta roda.

e Vilfredo Pareto (1848-1923), "quem equacionou a explicação que as classes dirigentes desejavam, por meio da teoria das elites, que explica a estrutura social em dois níveis apenas: elite e massa."

Foi então Pareto quem passou a utilizar o termo elite "para representar a idéia de que as minorias dirigentes são constituídas de indivíduos especialmente qualificados - os eleitos - para conduzir o destino da maioria, que não tem aptidões especiais" (MARTINEZ,1933:8). A popularização do termo elite deu-se, então, a partir das reflexões de Pareto, que afirmou, segundo Silva (1986:389):

Formemos uma classe com as pessoas que apresentam os mais elevados índices no seu ramo de atividade e demos-lhe o nome de elite [...] Dessa maneira, teremos dois estratos na população: a) um estrato inferior, a não-elite [...]; b) um estrato superior, a elite, dividido em dois: I) a elite governante;II) a elite não governante. ${ }^{29}$

Mosca e Pareto são alguns dos precursores da teoria das elites. Por Teoria das Elites, segundo o Dicionário de Política (Bobbio, Matteucci \& Pasquino, 1997: 385), "se entende a teoria segundo a qual, em toda a sociedade, existe, sempre e

${ }^{29}$ Cf. PARETO, V.(1935), The mind and society, London, v.3, p. 1.423-4. 
apenas uma minoria que, por várias formas, é detentora do poder, em contraposição a uma minoria que dele está privada". Mosca relaciona elite ao poder político, alegando que em todas as sociedades existem duas classes de pessoas: a dos governantes e a dos governados. Pareto difundiu o termo elite com a tese segundo a qual em toda sociedade há uma classe superior - aristocracia ou elite - que detém geralmente o poder político e o poder econômico.

Segundo Bobbio, Matteucci \& Pasquino (1997:386-387):

A fortuna da teoria das Elites, ao nascer, dependeu do fato de que, não obstante a pretensão de valer como [...] primeira teoria científica no campo da política, surgiu como uma fortíssima carga polêmica antidemocrática e anti-socialista, que refletia bem o 'grande medo' das classes dirigentes dos países onde os conflitos sociais eram ou estavam para se tornar mais intensos. [...] A teoria das minorias governantes caminha pari passu com uma concepção essencialmente desigual da sociedade, como uma visão estática ou inteiramente cíclica da história, com uma atitude mais pessimista do que otimista da natureza humana, com uma incredulidade quase total em relação aos benefícios da democracia, com uma crítica radical do socialismo, como criador de uma nova civilização, e com uma desconfiança que se aproxima do desprezo pelas massas portadoras de novos valores. Esta concepção, que faz parte da teoria das minorias governantes, é sustentada por Mosca e Pareto.

A Teoria das Elites tem grande repercussão na ciência política dos Estados Unidos, desde que foi acolhida e divulgada por Harold D. Lasswell. Numa de suas obras principais (Who gets what, whem, how, 1936) ${ }^{30}$, abre o primeiro capítulo com estas palavras:

O estudo da política é o estudo da influência daqueles que a exercem [...]. Aqueles que têm influência são aqueles que tomam a maior parte daquilo que se pode tomar. Os valores disponíveis podem ser classificados como valores de deferência, de renda, de segurança. Aqueles que obtêm a maior parte delas são Elites, o resto é massa (BOBBIO, MATTEUCCI \& PASQUINO,1997:387388).

Wright Mills é um outro autor que, com sua polêmica obra $A$ elite no poder, de 1956, define a elite no poder como:

\footnotetext{
${ }^{30}$ Em português: Quem obtém o quê, quando e como.
} 
[...] composta de homens que se acham em posições tais que Ihes é possível transcender o ambiente do homem comum e ocupam aquelas posições estratégicas da estrutura social em que estão atualmente concentrados os instrumentos de poder, a riqueza e a celebridade (BOBBIO, MATTEUCCI \& PASQUINO, 1997:388).

Os autores marxistas são os que fazem a crítica mais radical contra a Teoria das Elites. A sociedade, nesta perspectiva, não é vista como uma contraposição entre Elite e massa, mas sim como um conjunto de relações entre dominantes e dominados. Na visão elitista, ao contrário dos marxistas, a relação entre Elite e massa não é necessariamente antagônica.

\subsection{Elite intelectual, ou a intelligentsia}

A posse do conhecimento é uma das características que distingue um grupo de outros, como é o caso de professores universitários em nossa sociedade. Eles compõem o grupo da chamada "elite intelectual". Este tipo de elite também é conhecido como intelligentsia. O termo vem do russo e foi utilizado pela primeira vez em meados do séc. XIX. Em seu uso mais geral, descrevia a pequena elite cultural que recebera uma educação do tipo europeu ocidental de então. Segundo Silva (1986:623):

Nas sociedades ocidentais, o termo intelligentsia é amplamente usado para indicar principalmente uma pequena elite interna ou uma pretensa elite de escritores e dignitários culturais. Não se pode negar que tais grupos têm identidade própria e até possuem, eventualmente, certa influência social e política [...]. Mas, embora possa ter mais ou menos prestígio em uma sociedade ocidental do que em outra, esse grupo não é nitidamente diferenciado de outros segmentos das classes profissionais, nem estritamente separado da classe média como um todo.

Mas, conforme destaca o próprio autor consultado, nas sociedades menos desenvolvidas (o que inclui a Rússia do século XIX), a elite intelectual não cresceu com a sociedade como um todo e não estava ligada a outros grupos da classe média. Na antiga sociedade soviética, a expressão "intelligentsia labutante" é usada para distinguir todos os que não são operários e camponeses, ou seja, todos os que se ocupavam apenas de atividades manuais. 
A princípio, a palavra foi usada principalmente para o que se pode chamar 'a nata dessa elite' - os escritores, críticos literários, cientistas e professores de universidades. Durante o século XX seu uso foi estendido, num sentido mais amplo, às classes profissionais - em particular aos advogados, professores e médicos. (1986:624)

Pode-se observar, então, que os professores universitários - objeto deste estudo - são considerados "elite intelectual" ou intelligentsia desde o século XIX. São eles também - e isso vale até hoje - que se destacam como cientistas, escritores e críticos literários, por exemplo, acumulando todas as características comuns da intelligentsia, no seu sentido original. Nas ciências sociais, o uso deste termo é associado com a obra de K. Mannheim, que acentua a autonomia da intelectualidade em face das determinações de classe, em contraste com a visão marxista. É o marxista italiano Antonio Gramsci, em sua obra Os intelectuais e a organização da cultura, quem tenta resolver esta questão de autonomia relativa ou não da elite intelectual em relação às determinações de classe.

Gramsci (1978:3) inicia sua obra com a pergunta: "Os intelectuais constituem um grupo social autônomo e independente ou cada grupo social possui sua própria categoria especializada de intelectuais?". No estudo da formação do intelectual, o autor distingue o "intelectual orgânico" do "intelectual tradicional". Os professores, clérigos e administradores são deste último tipo enquanto os intelectuais orgânicos são os capitalistas que criam para junto de si os especialistas em economia, o técnico industrial e, nos dias de hoje, os profissionais de publicidade e as relações públicas da empresa. Gramsci acreditava que os intelectuais orgânicos estão ativamente envolvidos na sociedade lutando para mudar mentalidades e expandir mercados, sempre em movimento tentando fazer novos negócios enquanto que os intelectuais tradicionais parecem permanecer mais ou menos no mesmo lugar.

Vale observar que, para Gramsci (1978:7), todo homem é um intelectual ou um filósofo. Nas suas palavras:

Todos os homens são intelectuais, poder-se-ia dizer então; mas nem todos os homens desempenham na sociedade a função de intelectuais. Quando se distingue entre intelectuais e nãointelectuais, faz-se referência, na realidade, tão-somente a imediata função social da categoria profissional dos intelectuais, isto é, levase em conta a direção sobra a qual incide o peso maior da atividade profissional específica, se na elaboração intelectual ou se no esforço muscular-nervoso. Isso significa que, se se pode falar de intelectuais, é impossível falar de não-intelectuais, porque não 
existem não-intelectuais. [...] Não existe atividade humana da qual se possa excluir toda intervenção intelectual, não se pode separar o homo faber do homo sapiens. Em suma, todo homem, fora de sua profissão, desenvolve uma atividade intelectual qualquer, ou seja, é um 'filósofo', um artista, um homem de gosto, participa de uma concepção do mundo, possui uma linha consciente de conduta moral, contribui assim para manter ou para modificar uma concepção do mundo, isto é, para promover novas maneiras de pensar.

Para este autor, o intelectual deve ter uma vida ativa, prática, de construtor, de organizador, de "persuasor permanente" e não apenas de orador. A escola é a instituição que tem a função de elaborar os intelectuais de diferentes níveis e de criar as especializações. A escola e as universidades preparam os intelectuais para serem distintos dos outros grupos, por serem lugar da chamada "alta cultura". Daí, pode-se inferir que as universidades são formadas por uma elite intelectual de professores, pesquisadores e etc que têm a função de expandir o número de integrantes dessa elite, educando os alunos para desempenharem tal papel num futuro próximo. As associações entre instituição de ensino (escola e universidade), poder, classes sociais e formação da elite intelectual são interessantes, mas complexas, não sendo impossível desenvolvê-las nos limites desta monografia. Por ora, vale reter que os intelectuais formam uma elite especial nas nossas sociedades e que a universidade reserva, hoje, um dos maiores espaços para ela se desenvolver.

Sobre isso trata também Edward Said, que elabora uma crítica aos intelectuais que, após desenvolverem um profissionalismo e uma especialização extremada, acabam se alienando. Para esse autor, o intelectual deve ser um amador atuando à margem do poder e não um especialista confinado em sua área de pesquisa. Said (2005:25), afirma:

[...] quero também insistir no fato de o intelectual ser um indivíduo com um papel público na sociedade, que não pode ser reduzido simplesmente a um profissional sem rosto, um membro competente de uma classe, que só quer cuidar de suas coisas e de seus interesses. A questão central para mim, penso, é o fato de o intelectual ser um indivíduo dotado de uma vocação para representar, dar corpo e articular uma mensagem, um ponto de vista, uma atitude, filosofia ou opinião para (e também por) um público. 
Em última análise, o que estes autores - Gramsci, Said, dentre outros questionam é qual é o verdadeiro papel do intelectual, qual é a sua vocação e quais devem ser os seus princípios norteadores.

A partir destas reflexões iniciais desenvolvidas nesses primeiros capítulos, no capítulo seguinte serão apresentadas algumas características da elite intelectual de Brasília, especialmente o grupo de professores da Universidade de Brasília (UnB). Além disso, serão buscadas as possíveis relações entre essa elite intelectual e o lazer. Entende-se que o lazer é uma das atividades "escolhidas" que podem ajudar a compor um desenho possível da intelligentsia da capital do país.

\section{CAMINHOS PERCORRIDOS E ANÁLISE DAS ENTREVISTAS}

Esta pesquisa é tanto qualitativa quanto quantitativa no que diz respeito às técnicas utilizadas para coleta de dados e às análises realizadas. Inicialmente foi feito um levantamento bibliográfico sobre os temas que foram o núcleo teórico dessa monografia: Brasília, lazer e elite (intelectual). No entanto, como um dos objetivos era conhecer o que a elite intelectual de Brasília - especialmente professores da Universidade de Brasília (UnB) - costuma fazer no seu tempo livre, optou-se pela técnica da entrevista individual estrutural dirigida, que consiste na aplicação de um questionário predeterminado com uma maioria de perguntas fechadas sem nenhum ou quase nenhum papel ativo do entrevistador.

Nesse caso, as perguntas das entrevistas foram lidas tais quais estavam escritas no roteiro padrão ${ }^{31}$, para cada entrevistado separadamente; suas respostas foram audiogravadas e posteriormente transcritas na íntegra. O entrevistador não fez nenhuma alteração nas perguntas ao longo das entrevistas.

\footnotetext{
${ }^{31} \mathrm{Cf}$. roteiro da entrevista no anexo.
} 
Foram realizadas, no mês de março de 2005, 14 entrevistas com professores da UnB - sendo 10 homens e 04 mulheres - dos seguintes cursos: enfermagem, nutrição, medicina, ciência política, direito, relações internacionais, geologia, educação física, engenharia elétrica, arquitetura, lingüística, matemática, computação e música. Os cursos foram escolhidos aleatoriamente, procurando alternar as áreas de exatas, biológicas e humanas, ou conforme a disponibilidade dos professores em conceder entrevista.

A faixa etária dos entrevistados é composta entre 31 e 61 anos de idade, conforme ilustra o gráfico 1.

GRÁFICO 1: Idades dos entrevistados

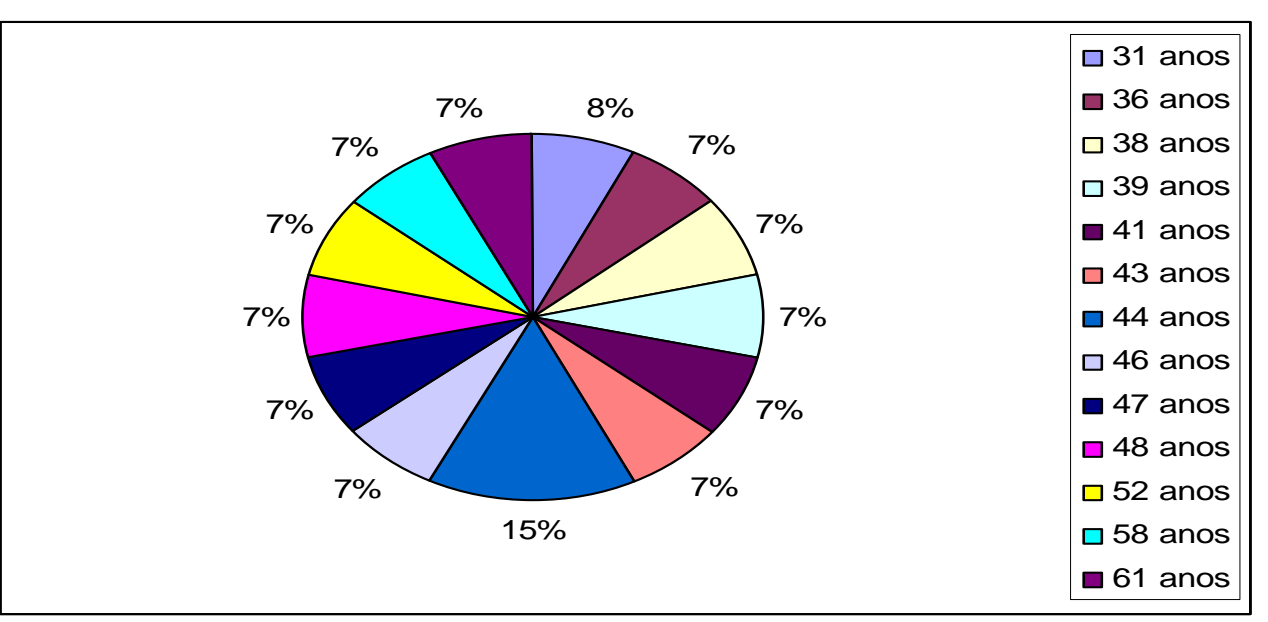

Dentre os entrevistados, embora $100 \%$ deles trabalhem na UnB, nota-se que, conforme ilustra o gráfico $22 \%$ possuem outro emprego.

GRÁFICO 2: Professores que possuem outra profissão

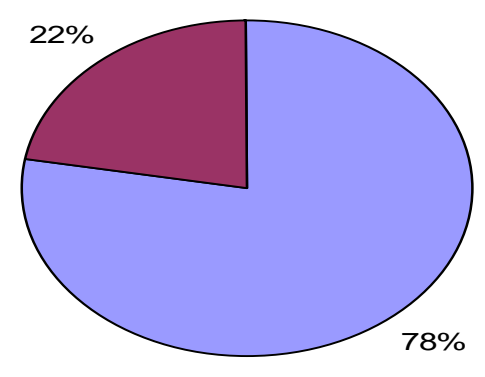

$\square$ professor universitário da UNB

$\square$ mais de uma profissão 


\subsection{Perfil sócio-econômico dos entrevistados}

Considerando o salário mínimo de $\mathrm{R} \$ 260,00$ (duzentos e sessenta reais), em março de 2005, pode-se perceber que a faixa salarial dos professores entrevistados varia entre 10 e 32 salários mínimos, sendo que 50\% deles diz receber entre 16 e 21 salários mínimos, conforme mostra o gráfico 3.

\section{GRÁFICO 3: Faixa salarial dos entrevistados}

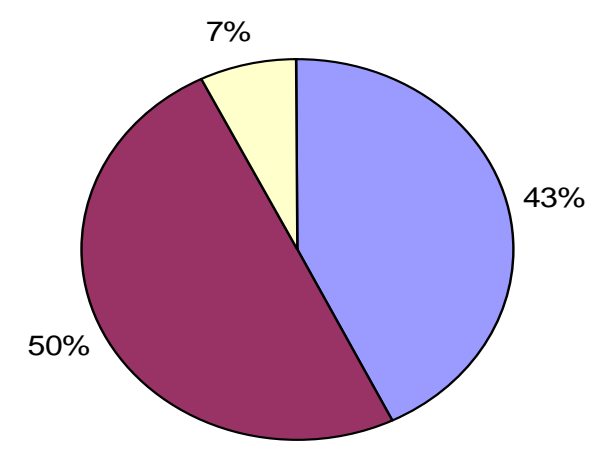

$\square$ de 10 a 15 salários mínimos

$\square$ de 16 a 21 salários mínimos

$\square$ de 28 a 32 salários mínimos

Quanto ao grau de instrução dos entrevistados, observa-se no gráfico 4 que $71 \%$ deles - a maioria - possui título de doutor. O menor grau de instrução dos professores entrevistados foi o mestrado.

GRÁFICO 4: Grau de instrução dos entrevistados

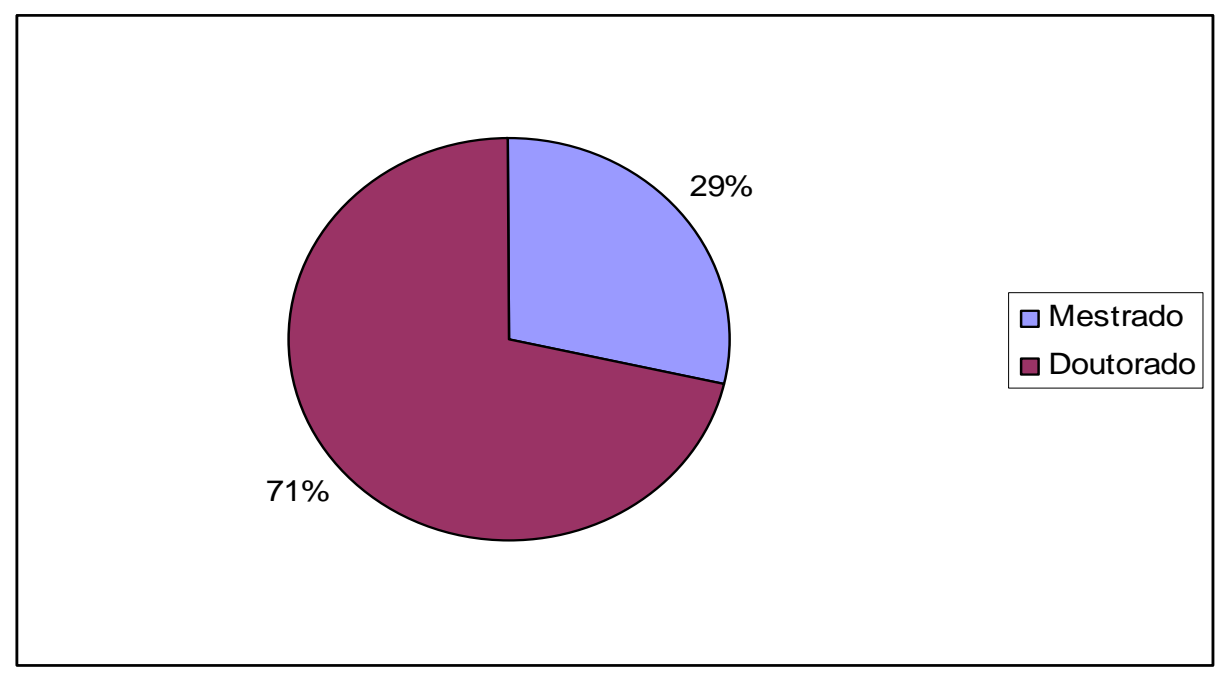


Interessante observar que a maioria dos pais dos entrevistados (36\%) possui curso superior completo enquanto que 29\% das mães dos entrevistados possui curso superior completo. A percentagem das mães que possuem primeiro grau incompleto é maior do que os pais, o que mostra que as mães possuem graus de instrução inferiores aos pais dos entrevistados.

GRÁFICO 5: Grau de instrução dos pais dos entrevistados

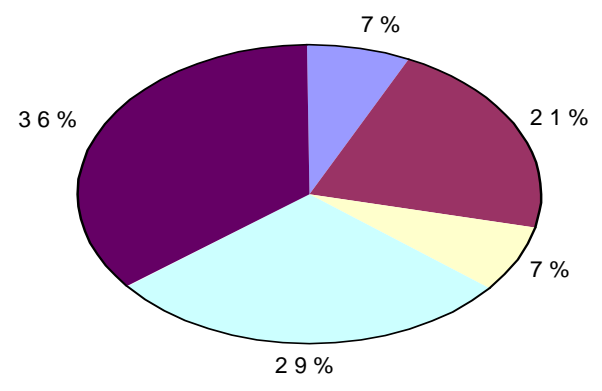

$\square$ prim eiro grau incom pleto

$\square$ prim eiro grau com pleto

$\square$ segundo grau

in com pleto

$\square$ segundograu completo

$\square$ superior com pleto

GRÁFICO 6: Grau de instrução das mães dos entrevistados

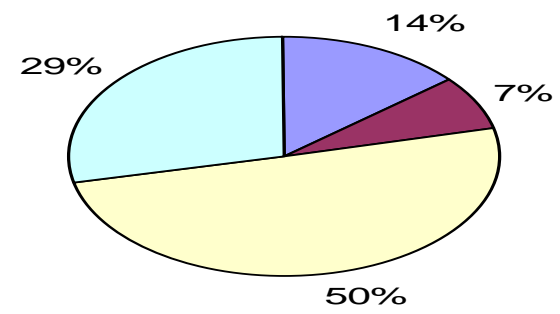

$\square$ primeiro grau

incompleto

$\square$ primeiro grau

completo

$\square$ segundo grau

completo

$\square$ superior completo

A metade dos entrevistados declarou ter 02 carros em sua residência enquanto $26 \%$ declarou possuir apenas 01 e $7 \%$ declarou ter 03 carros. $44 \%$ dos entrevistados possui 02 aparelhos de televisão (TV) enquanto $14 \%$ possui 05 aparelhos e $21 \%$ possui 04. 
GRÁFICO 7: Quantidade de aparelhos de TV por residência

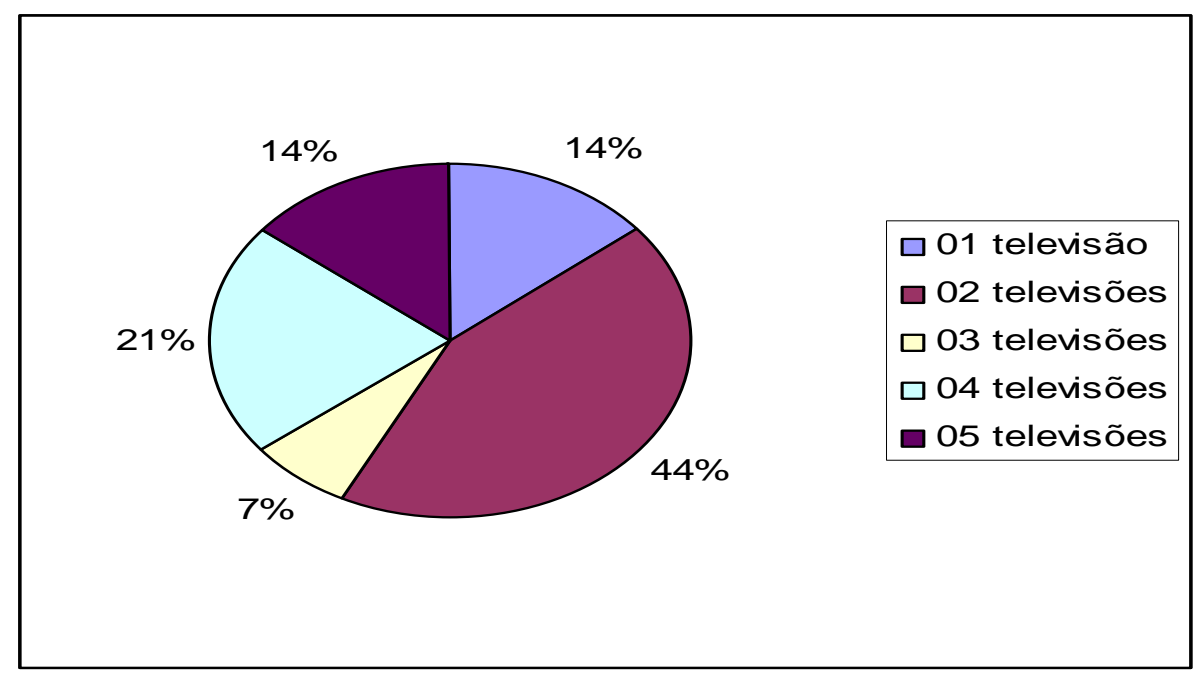

Dos entrevistados, $72 \%$ declarou possuir 01 aparelho de videocassete, enquanto que $65 \%$ declarou possuir 01 aparelho de DVD. Interessante observar que $21 \%$ declarou possuir 02 videocassetes e 14\% declarou possuir 02 aparelhos de DVD. $21 \%$ dos professores entrevistados possui 01 home theatrer. A maioria dos entrevistados (35\%) declarou possuir apenas 01 aparelho de telefone em casa, enquanto que $29 \%$ declarou possuir 02 e a mesma quantidade de professores (29\%) declarou possuir 03 aparelhos de telefone. A maioria dos entrevistados (58\%) respondeu possuir 02 telefones celulares, enquanto $21 \%$ possui 03 e apenas $7 \%$ não possui esse tipo de equipamento.

GRÁFICO 8: Quantidade de aparelhos de telefone fixo em casa

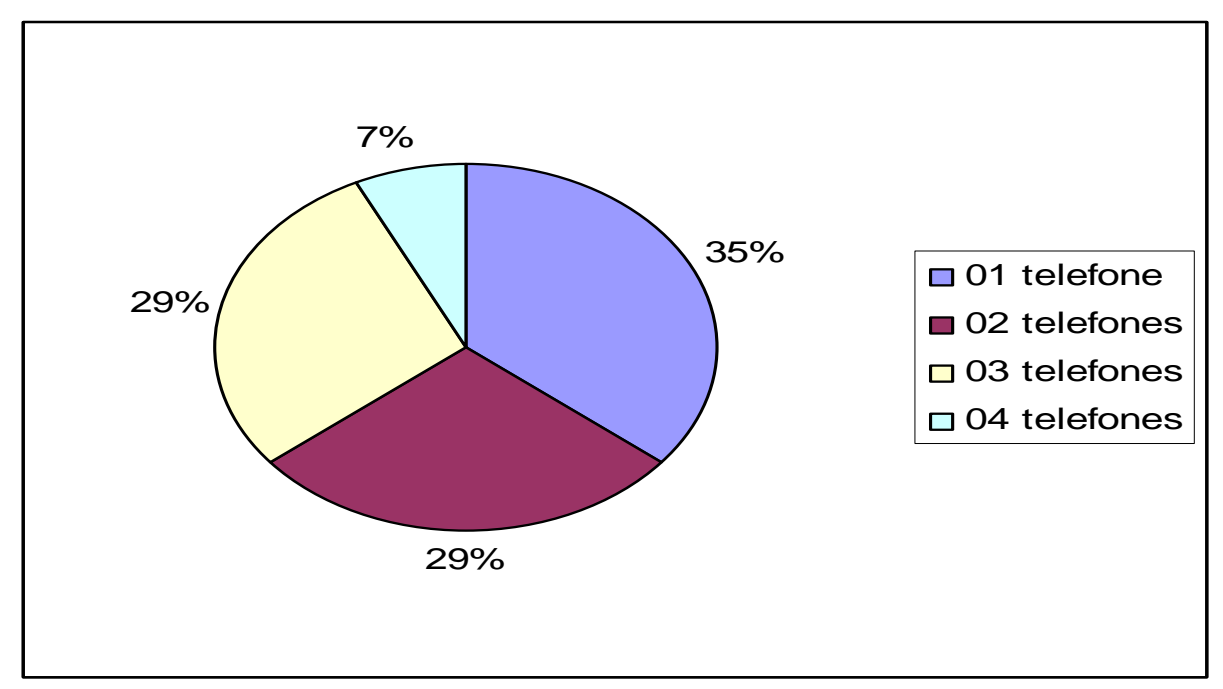


GRÁFICO 9: Quantidade de telefone celular por entrevistado

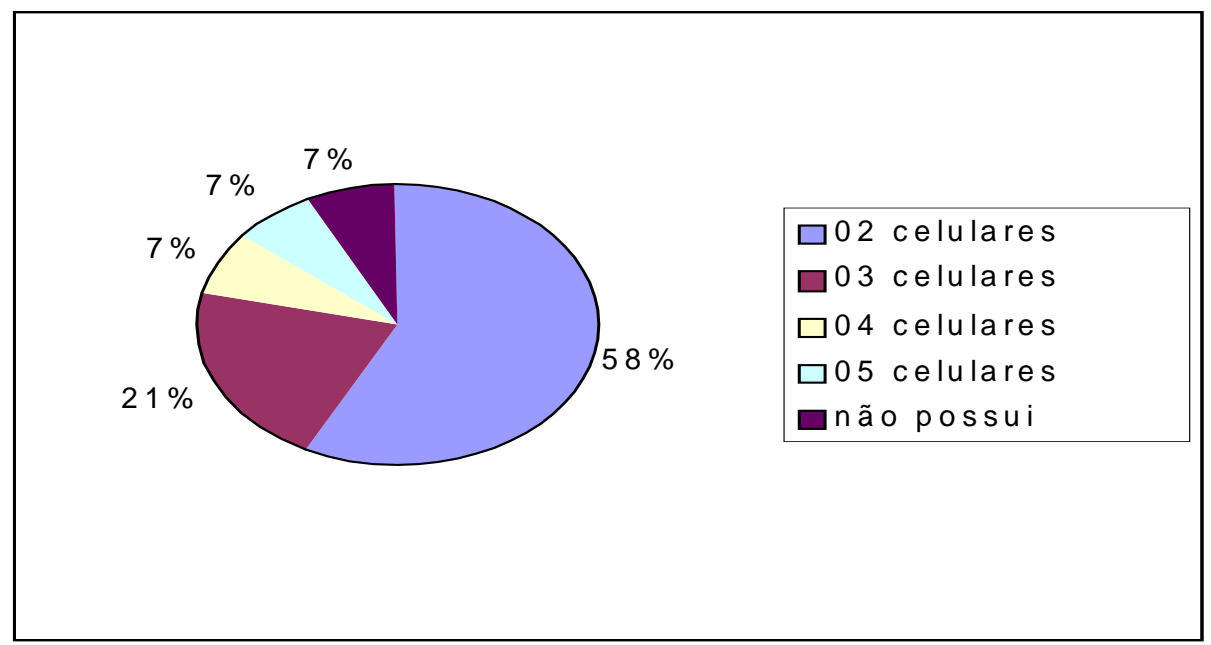

Dos quatorze professores entrevistados, $71 \%$ declarou ter apenas 01 geladeira, enquanto que $29 \%$ possui 02 . A metade dos entrevistados possui 02 computadores em casa, enquanto que 14\% possuem 03 e 36\% possuem apenas 01 computador. Pouco mais da metade dos entrevistados (51\%) declarou ter 03 banheiros em casa enquanto que $14 \%$ possui 04 e $7 \%$ possui 06 banheiros. A grande maioria dos professores entrevistados mantém 01 empregada em casa, enquanto que $14 \%$ declararam manter 02 e 14\% declarou não manter nenhuma empregada em casa.

Ao serem perguntados se se consideram membros da elite intelectual de Brasília, 14\% dos entrevistados responderam "sim", 51\% dos entrevistados responderam "acho que sim" e $21 \%$ responderam "não". Os professores que responderam "não", explicaram suas respostas afirmando:

"Pois não tenho influência política ou poder econômico"

"Pois não freqüento colunas sociais e não ligo para posição, cargo ou sobrenome."

"Pois não tenho doutorado."

"Formalmente não, as elites são congregações, devo estar de forma informal."

Dos professores que responderam "sim" ou "acho que sim", apareceram justificativas associadas a sua formação acadêmica e a profissão, como: 
"Acho que sim, pelo meu tipo de trabalho e consumo."

"Sim, pela minha profissão."

"Em certo sentido acho que sim, por ter opinião importante acho que faço parte."

"Sim, pois sou professor da UnB, escrevo artigos e pela minha tese de mestrado."

"Acho que sim, tenho estudado tanto, fiz doutorado."

\subsection{Valores dos entrevistados em torno do lazer}

Ao serem perguntados se o lazer é importante, 93\% dos entrevistados responderam "sim". Apenas 01 entrevistado respondeu "deve ser". As explicações para estas respostas exemplificam a abordagem funcionalista ${ }^{32}$ do lazer, sobretudo quando o relaciona com tudo o que é bom, em contraposição ao trabalho como algo penoso, cansativo e estressante. Outra característica que ganha destaque nas falas dos entrevistados é a idéia de lazer como recuperação dos cansaços, da rotina, do trabalho. O lazer é sempre pensado como o lado bom da vida em contraposição ao trabalho. Mesmo o trabalho prazeroso precisa de um lazer compensatório, pois "o homem não foi feito para o trabalho."

As justificativas dos entrevistados para a opinião de que lazer é importante são as seguintes:

"Para distrair."

" É fundamental, é a forma que temos para diminuir o stress, traz alegria."

"Sim, claro, eu acho que ele serve para diminuir o stress."

"Sim, pois se você não der uma pausa, o seu trabalho não renderá."

"Sim, pois é importante para a saúde."

"Sim, sem dúvida, assim como a atividade física, a alimentação e o trabalho. Porém, o seu tempo [do lazer] é menor."

"Sim, para você não entrar em rotina, para se motivar para o trabalho, para ser feliz."

${ }^{32}$ É o tipo de abordagem com uma visão romântica, moralista, compensatória e utilitarista do lazer. 
"Sim, pois o lazer permite reequilibrar as suas vocações. Mesmo com um trabalho prazeroso você não consegue satisfazer-se por completo, o lazer seria o complemento."

"Sim, porque o homem foi feito para o lazer e não para o trabalho."

"Sim, diverte a cabeça, ocupa a cabeça."

"Sim, rejuvenesce."

"Sim, você fica mais descansado para o trabalho."

"Deve ser. Todos dizem que é. Sim, mas não o valorizo tanto."

Apenas um professor considerou o seu trabalho como lazer e associou ambos à saúde:

"Sim, faz parte. O trabalho é um lazer, a minha profissão funciona como um lazer. Eu encaro o lazer como saúde."

Quando solicitados a explicarem como definiriam lazer, ócio e tempo livre, os professores apontaram algumas das características mais comumente associadas ao lazer, como o fato de ser atividade, de se realizar fora do tempo de trabalho e da obrigação, de dar satisfação ou prazer, de ser divertido e relaxante. O ócio é mais associado ao não fazer nada e, algumas vezes, traz consigo um caráter negativo e de perda de tempo. Os entrevistados responderam:

"É fazer o que gosta fora do trabalho."

"Atividade que a gente faz por pura satisfação."

"Atividade que Ihe causa satisfação."

"Qualquer atividade que não tenha obrigação. Estas coisas deveriam ser iguais, mas competem entre si."

"É poder relaxar, atividades sem o compromisso de reflexão. Mero divertimento."

"Lazer é saúde, ócio é ficar sem fazer nada e tempo livre é ser uma pessoa idealizada."

"O ócio é a perda de tempo, é negativo. O lazer é aproveitar o tempo para o prazer, é positivo. Já o tempo livre é o tempo sem atividade profissional, que pode ser tanto para o ócio quanto para o lazer." 
"O lazer você pratica no tempo livre, fora do trabalho. Já o tempo livre é a hora em que você não está trabalhando e o ócio é o fazer nada durante o tempo livre."

"Ócio dá idéia de perda de tempo, no lazer você utiliza o tempo para fazer algo agradável e o tempo livre está associado a nenhuma obrigação, pode ser tanto para o lazer quanto para o ócio."

"É um tempo para você se dedicar as coisas pessoais, sem obrigação."

$\mathrm{Na}$ afirmação seguinte, fica evidente que o entrevistado vê o não fazer nada do ócio como um tempo de não diversão, o que revela o quanto as pessoas podem também associar a diversão com o fazer alguma coisa, produzir, seguir um ritmo, acompanhar um grupo, agir...

"Vejo o lazer como sendo um tempo para se divertir, o ócio como o fazer nada, você não se diverte e o tempo livre é a união desses dois."

Curiosamente, um entrevistado associou tempo livre como sendo o tempo obrigatório do trabalho:

"Lazer é o tempo para atividades que você delibera, são atividades prazerosas e são estruturadas de acordo com as suas vontades. $O$ tempo livre é aquele que você se dedica ao trabalho, é obrigatório. Já o ócio é o tempo o qual você não está fazendo transações com outras pessoas, não é produtivo (não quero dizer que somos obrigados a produzir.)."

"O lazer é a atividade que te dá prazer; o ócio é o tempo de inatividade; e o tempo livre é o tempo que pode ser aproveitado com atividades não profissionais."

"No lazer você gosta do que está fazendo; no ócio você está parado e no tempo livre você escolhe se vai utilizá-lo para o lazer ou para o ócio."

Ao serem perguntados se são livres no seu tempo livre, os professores deram respostas variadas e explicaram das seguintes maneiras:

"Não, por causa das obrigação familiares (mulher)."

"Razoavelmente, por causa dos compromissos, família grande e tempo curto (mulher)." 
"Não totalmente, devido às obrigações familiares (homem)."

"Mais ou menos, algumas vezes tenho que estudar no meu tempo livre (homem)."

"Mais ou menos. Você sempre estará condicionado com as suas obrigações (homem)."

"Sim, na maioria das vezes posso usá-lo de acordo com os meus interesses (homem)."

"Sim, não tenho que pedir nada para ninguém nem dar satisfação do que faço (homem)."

"Sim, é sem trabalho (homem)."

"Sim, faço o que quero na forma que eu achar melhor (mulher)."

"Sim, pois tenho a liberdade de fazer o que eu quero (mulher)."

"Não, não tenho tempo livre (homem)."

Uma professora respondeu que se sente culpada por ter tempo livre, mas para outra pergunta da entrevista, explicou que lazer é saúde e disse que lazer é importante por causa da saúde. Por que haveria culpa em cuidar da sua saúde? Não estaria essa resposta tentando mostrar que ela é uma pessoa produtiva, responsável, que não desperdiça seu tempo - qualidades de alguém na sua posição profissional e de gênero?

"Não, pois acho que é deixar de fazer algo; me sinto culpada (mulher)."

Um professor que disse ser livre porque faz o que quer, em outra pergunta da entrevista $^{33}$, responde que gostaria de escrever mais no seu tempo livre mas não o faz por falta de organização, o que mostra uma certa contradição em sua fala:

"Sim, pois faço o que quero (homem)."

Um dos entrevistados respondeu curiosamente que seus hobbys ocupam muito o seu tempo livre, apresentado essa justificativa como argumento para uma

\footnotetext{
${ }^{33}$ Pergunta: Existe alguma coisa que você gostaria de fazer no seu tempo livre mas você não faz? Por quê? O que te impede de fazer?
} 
ressalva quando afirmou ser livre no seu tempo livre, o que revela que ele não associa o hobby como algo que se pode fazer no tempo livre.

"Sim, embora alguns dos meus hobbys ocuparem muito tempo me sinto livre, não me sinto angustiado (homem)."

\subsection{Hábitos de lazer dos professores da Universidade de Brasília}

Para a pergunta "o que você mais gosta de fazer no seu tempo livre", "ler" apareceu na maioria das respostas (42\%), "ouvir música" ficou em segundo lugar (28\%), "ir ao cinema" e "caminhar" apareceram em terceiro lugar (21\%). Outras atividades foram apontadas, dentre elas: "conversar ou bater papo", "ir ao teatro", "ver filmes", "viajar", "ir ao shopping", "correr", "jogar bola", "dormir", "escrever", "ir a restaurante".

Ao serem perguntados se viajaram no período entre janeiro de 2004 e março de 2005, 86\% dos entrevistados responderam que sim. A maioria das viagens foram feitas como lazer, turismo ou nas férias. O segundo motivo mais comum para as viagens é o trabalho (congressos, por exemplo). Os destinos e os motivos das viagens são os que seguem na tabela 1.

TABELA 1: Destinos e motivos das viagens dos entrevistados

\begin{tabular}{|l|l|l|}
\hline \multicolumn{1}{|c|}{ LOCAL } & \multicolumn{1}{|c|}{ MOTIVO } & \multicolumn{1}{c|}{$\begin{array}{c}\text { MEIO DE } \\
\text { TRANSPORTE }\end{array}$} \\
\hline Bahia e Montevidéo & Lazer & Avião e ônibus \\
\hline Florianópolis e Vitória & Congressos & Avião \\
\hline Estados Unidos & Trabalho e lazer & Avião \\
\hline $\begin{array}{l}\text { Rio de Janeiro e Minas } \\
\text { Gerais }\end{array}$ & Turismo & Carro \\
\hline Cuiabá e Uberlândia & Férias e velório & Carro \\
\hline Maceió & Turismo & Avião \\
\hline $\begin{array}{l}\text { Porto Velho, Porto Alegre, } \\
\text { Teresina, Fortaleza, Belo } \\
\text { Horizonte, Palmas, Vitória }\end{array}$ & Trabalho e turismo & Avião \\
\hline
\end{tabular}




\begin{tabular}{|l|l|l|}
\hline $\begin{array}{l}\text { São Paulo, Caldas Novas, } \\
\text { Estados Unidos }\end{array}$ & Férias e trabalho & Avião e carro \\
\hline $\begin{array}{l}\text { Salvador, Fortaleza e } \\
\text { Estados Unidos }\end{array}$ & Trabalho e lazer & Avião \\
\hline $\begin{array}{l}\text { Europa e Fortaleza } \\
\text { Garça, Caldas Novas }\end{array}$ & Férias & Avião \\
\hline São Paulo, Piauí, Goiânia & Passeio e carro \\
\hline
\end{tabular}

Como podemos notar na tabela acima, dentre os destinos das viagens, várias vezes foram citadas viagens ao Exterior, o que torna este grupo num público privilegiado, além do fato de viajarem várias vezes ao ano.

Os lugares de lazer em Brasília mais freqüentados pelos professores entrevistados foram:

TABELA 2: Lugares de lazer de Brasília mais freqüentados pelos entrevistados

\begin{tabular}{|l|l|}
\hline Parque da Cidade & $42 \%$ \\
\hline Bares & $35 \%$ \\
\hline Cinema & $35 \%$ \\
\hline Parque Olhos d'Água & $21 \%$ \\
\hline Shopping Center & $21 \%$ \\
\hline Teatro & $14 \%$ \\
\hline Clubes & $14 \%$ \\
\hline
\end{tabular}

Ao se analisar esses dados, percebemos que $63 \%$ dos entrevistados freqüentam alguns dos parques citados e que $21 \%$ freqüenta os shoppings e apenas $14 \%$ freqüenta clubes.

Quando foram perguntados o que achavam das opções de lazer existentes em Brasília, a maioria dos entrevistados não reclamou ou fez críticas severas, apesar de aparecerem considerações sobre os preços altos e de tenderem a avaliar negativamente Brasília se tomarem como referência de comparação as opções de capitais reconhecidas como centros culturais, tais como São Paulo ou Rio de Janeiro. As respostas são as seguintes: 
"Tem bastante coisa."

"Acho que tem bons shows, peças e filmes. Tem uma boa qualidade de vida."

"Caras, bastante caras, mas tem muita opção."

"Têm melhorado bastante. Tem uma boa oferta. Não estamos no eixo Rio - São Paulo, mas está bom. As vezes cai, mas levanta. Há uma tendência de melhora nos últimos anos. Poderia ter mais opções. Falta oferta e por isso é caro. Poderia, por exemplo, ampliar a programação dos eventos, assim teriam mais público e o custo diminuiria. As temporadas populares do governo anterior funcionaram, esse ano acabou, deveriam ser fixas. Os programadores de evento deveriam utilizar também os espaços das outras regiões administrativas."

"São boas, não são comparáveis as de São Paulo, mas não tenho do que me queixar."

"Acho que tem muita opção, o problema é a distância e o fato de estar vinculado a gastos. Tem opções, apenas tem que saber procurar de acordo com o perfil da pessoa."

"Para Brasília são o suficiente. Tem muito cinema, boas casas de dança e bons shows."

"A parte de música clássica é muito boa; no cinema temos boas salas com boas programações; o teatro é muito caro, mas são bons; os parques são bons; e as exposições são boas."

"Tudo é caro, não sei avaliar o que falta. Procurando tem. Eu tenho a impressão de que aqui tem mais vida cultural do que se imagina, com bastante diversificação."

"Acho razoável, quando vamos para fora vejo que a diferença é a praia, além da parte cultural, cinemas e biblioteca (bons) fazem falta. Temos bons restaurantes."

Apenas um professor avaliou de forma negativa as opções de lazer da cidade de Brasília, afirmando:

"São muitos fracas, por exemplo, uma coisa que é fundamental é a utilização do Lago Paranoá, que não é utilizado. Escandalosamente pobre."

Ao serem perguntados se praticam algum esporte, a maioria respondeu "sim" (64\%), evidenciando que essa população entrevistada procura cuidar do corpo e da saúde. O esporte apontado pela maioria dos entrevistados (35\%) foi a musculação, 
feita em academias especializadas. Caminhar e correr foram as atividades esportivas que ocuparam o segundo lugar (28\%); os parques da cidade e o "eixão" são os lugares mais usados para essas atividades. Jogar bola e pedalar são os outros esportes que aparecem, em menor quantidade, nas respostas. O Centro Olímpico da UnB aparece apenas em duas entrevistas como um espaço de esporte e de lazer utilizado pelos professores entrevistados.

Os entrevistados indicaram, espontaneamente, seus lazeres mais caros e mais baratos. A opção de lazer que mais aparece indicada como cara é viagem (ou dentro do Brasil ou para o exterior) e o lazer mais barato apontado pelos entrevistados é caminhar ou correr. Essas respostas mostram que, apesar de caras, as viagens fazem parte das opções de lazer da elite intelectual de Brasília, aqui representada pelos professores da UnB. Essas informações aparecem na tabela 3. a seguir.

TABELA 3: Lazeres caros e baratos realizados pelos entrevistados

\begin{tabular}{|c|c|c|}
\hline ENTREVISTADOS & MAIS CAROS & MAIS BARATOS \\
\hline 01 & Nunca fiz lazer caro & Não tem \\
\hline 02 & Viagens & Caminhada no parque \\
\hline 03 & Viagem para Paris & Ler, ir ao cinema \\
\hline 04 & Viagem pelo Brasil & Andar \\
\hline 05 & Viagem para o exterior & Caminhar \\
\hline 06 & Ir ao teatro & $\begin{array}{l}\text { Orquestra sinfônica, caminhar, } \\
\text { Teatro Nacional }\end{array}$ \\
\hline 07 & Viagens & Viagem curta \\
\hline 08 & Viagem de bicicleta & Correr na chácara \\
\hline 09 & Esquiar & Correr, Parque da Cidade \\
\hline 10 & Não consigo dizer & Não consigo avaliar \\
\hline 11 & Viajar & Ir ao botequim \\
\hline 12 & Viagem & Ir ao clube, jogar baralho \\
\hline 13. & Viagens & Caminhar \\
\hline 14. & $\begin{array}{l}\text { Não sei o que é lazer caro, } \\
\text { acho que é viajar }\end{array}$ & Pescar \\
\hline
\end{tabular}




\section{CONSIDERAÇÕES FINAIS}

Primeiramente, percebe-se que mais da metade dos entrevistados (51\%) se consideram como membros da elite de Brasília. Vale ressaltar aqui que mesmo respondendo que sim, muitos se surpreenderam ao saber o tema da monografia, e normalmente sorriam, ou então faziam algum comentário irônico sobre ele/ela ser membro de uma elite. Cabe relembrar também que $97 \%$ dos entrevistados recebem entre 10 e 21 salários mínimos, e que apenas 7\% deles recebem entre 28 a 32 salários mínimos - sendo que os que estão nesse grupo possuem outros meios de renda.

Outro fato importante - que já era, em certa medida, esperado - é que a totalidade dos entrevistados considera o lazer importante, utilizando argumentos da abordagem funcionalista para justificar sua resposta, o que nos revela que as pessoas não possuem um olhar crítico ao lazer, que o vêm como sendo algo sempre bom, pois serve para prepará-los para o trabalho, e não se perguntam, em momento algum, por que precisam de algo para compensar o trabalho. Além disso, eles vêm o lazer como uma atividade (fazer algo, consumir) e o ócio como a falta de atividade, classificando o lazer como algo positivo e normalmente o ócio como algo negativo.

É nesse contexto, que aproveito para perguntar: Qual dos dois (lazer ou ócio), nessa visão, é a que o sistema capitalista prefere? Faço essa pergunta, porque se é nisso que a elite intelectual acredita como sendo lazer e ócio, fazendo com que o lazer seja mais um produto da sociedade capitalista, e o ócio como algo maléfico, onde é que vai entrar o momento para as pessoas refletirem sobre a sociedade em que vivem, analisar as suas diferenças sociais e paradoxos? Por que nenhum dos 
professores entrevistados, enquanto representantes da elite intelectual de Brasília, valorizou o lazer como tempo para reflexão crítica em relação à sociedade?

Entendo que esta pesquisa alcançou suas metas iniciais, tendo mostrado, além de dados interessantes obtidos em grande parte através das entrevistas integrantes, revelou que ainda há muito por fazer no campo de estudos do lazer, como, por exemplo, tentar descobrir a sua finalidade, a necessidade de sua existência para as pessoas. Afinal, como já vimos nos primeiros capítulos o lazer tal como o concebemos hoje surge como uma compensação para o trabalho e me questiono se é essa realmente a função do lazer, será que realmente é necessária, nos tempos atuais, essa separação, distinção, entre lazer e trabalho? Será que um trabalho prazeroso necessita de tempo para o lazer? 


\section{REFERÊNCIAS:}

\section{Bibliográficas:}

BACAL, Sarah S. (1978). Realidade e uso do tempo livre. (dissertação de mestrado). Escola de comunicação e artes da Universidade de São Paulo. Apud SANT'ANA, Denise Bernuzzi de. (1994). O prazer justificado. História e lazer. São Paulo: Marco Zero.

BICCA, Briane Panitz (1997), Um passeio por Brasília. In: BRAGA, Andréa da Costa, FALCÃO, Fernando A. R. Guia de urbanismo, arquitetura e arte de Brasília. Brasília: Fundação Athos Bulcão.

BOBBIO, Norberto; MATTEUCCI, Nicola; PASQUINO, Gianfranco (1997). Dicionário de Política, Vol. 1., Brasília: Editora Universidade de Brasília.

BRAGA, Andréa da Costa; FALCÃO, Fernando A. R. (1997), Guia de urbanismo, arquitetura e arte de Brasília. Brasília: Fundação Athos Bulcão.

BRASÍlIA de asas abertas pra você. ADETUR-DF (atualmente SETUR),. GDF,. UNESCO.

BRUHNS, Heloisa Turini. (2002). De Grazia e o lazer como isenção de obrigações. In: BRUHNS, Heloisa Turini. (org.), Lazer e ciências sociais: diálogos pertinentes. São Paulo: Chromos ( coleção: Lazer, esporte \& sociedade.)

CAMARGO, Luiz O. Lima.(2003) O que é lazer. São Paulo: Brasiliense ( coleção primeiros passos;172) $2^{\circ}$ reimpressão da $3^{\circ}$ ed. de 1992.

CASTRO, Celso Antonio Pinheiro de. (2002) Sociologia aplicada ao Turismo. São Paulo: Atlas. $1^{\circ} \mathrm{ed}$. 
DICIONÁRIO de Sociologia (1961). Rio de Janeiro: Globo

DUMAZEDIER, Jofre (1974). Sociologia empírica do lazer. São Paulo: Perspectiva.

EVENSON, Norma (1973). Two Brazilian Capitals. New Haven, Yale University Press. Apud FARRET, Ricardo L. (1985), O Estado, a questão territorial e as bases da implantação de Brasília. In: PAVIANI, Aldo (org.) Brasília, ideologia e realidade. São Paulo: Projetos.

EKER, Glen (1991). Leisure and lifestyle in selected writings of Karl Marx. New York: The Edwin Mellen Press. Apud VIEITEZ, Candido Giraldez.(2002) Marx, o trabalho e a evolução do lazer. In: BRUHNS, Heloisa Turini. (org.) Lazer e ciências sociais: diálogos pertinentes. São Paulo: Chronos (coleção: Lazer, esporte \& sociedade.)

FARRET, Ricardo L. (1985), O Estado, a questão territorial e as bases da implantação de Brasília. In: PAVIANI, Aldo (org.). Brasília, ideologia e realidade. São Paulo: Projetos.

. (1978), Growth Center Strategy: a case study of Brasília. Berkeley, University of Califórnia (tese mimeo). Apud: FARRET, Ricardo L. (1985), O Estado, a questão territorial e as bases da implantação de Brasília. In: PAVIANI, Aldo (org.). Brasília, ideologia e realidade. São Paulo: Projetos.

FEATHERSTONE, Mike.(1995) Cultura de consumo e pós-modernismo. São Paulo: Studio Nobel.

GONZALES, Suely Franco Netto (1985). As formas concretas da segregação residencial em Brasília. In: PAVIANI, Aldo (org.), (1985) Brasília, ideologia e realidade. São Paulo, Projetos.

GOSLING, David (1979). "Brasília". Third world Planning Review. Apud FARRET, Ricardo L. (1985), O Estado, a questão territorial e as bases da implantação de Brasília. In: PAVIANI, Aldo (org.) (1985), Brasília, ideologia e realidade. São Paulo: Projetos. 
GOUVÊA, Luiz Alberto de Campos (1998). Cidade e natureza: uma visão da construção da cidade brasileira no Planalto Central. A construção da Cidade. Brasília: departamento de Patrimônio Histórico e Artístico do Distrito Federal.

GRAMSCI, Antonio (1978) Os intelectuais e a organização da cultura, Rio de Janeiro: Civilização Brasileira.

GUIA especial Brasília Lazer e Negócios. Governo do Distrito Federal, Jornal de Brasília.

KELLER, Suzanne. (1967) O destino das elites. Rio de Janeiro: Forense.

KENT, Hollister. (1956). Vera Cruz: Brazil's New Federal Capital. Cornell University (tese mineo). Apud FARRET, Ricardo L. (1985), O Estado, a questão territorial e as bases da implantação de Brasília. In: PAVIANI, Aldo (org.). Brasília, ideologia e realidade. São Paulo: Projetos.

MANTERO, Juan Carlos. (2000). Turismo e lazer. In: SESC/ WLRA. Lazer numa sociedade globalizada. São Paulo: Sesc/Wrla.

MARTINEZ, Paulo. (1933). A teoria das elites. São Paulo: Scipione. (coleção: ponto de apoio)

MARX, Karl; ENGELS, Friederick. (1989) A Ideologia Alemã (Feuerbach), São Paulo: Hucitec.

OLIVEIRA, Juscelino Kubistchek de (1975). Por que Construí Brasília. Rio de Janeiro, Block Editores S.A., UNB.

PADILHA, Valquíria (2002) A indústria cultural e a indústria do lazer: uma abordagem crítica da cultura e do lazer nas sociedades capitalistas globalizadas. In: MULLER, Ademir; DACOSTA, Lamartine Pereira (ORGS.), Lazer e desenvolvimento regional, Santa Cruz do Sul: EDUNISC. 
, (2000). Tempo livre e capitalismo: um par imperfeito.Campinas, São Paulo : Editora Alínea.

PARETO, V.(1935), The mind and society, London, v.3. Apud: SILVA, Benedito. (1986). Unesco. Dicionário de Ciências Sociais. Rio de Janeiro: Fundação Getúlio Vargas.

PERALVA, Osvaldo. Brasília, (1988), Patrimônio da Humanidade (um relatório). Ministério da Cultura. Coordenadoria de comunicação social.

SAID, Edward. (2005) Representações do intelectual, As Conferências Reith de 1993, São Paulo: Companhia das Letras.

SANT'ANA, Denise Bernuzzi de. (1994). O prazer justificado. História e lazer. São Paulo: Marco Zero.

SCHUMPETER, Joseph Alois (1955). Imperialism and social class. New York: Meridian. Apud: KELLER, Suzanne. (1967) O destino das elites. Rio de Janeiro: Forense.

SILVA, Benedito. (1986). Unesco. Dicionário de Ciências Sociais. Rio de Janeiro: Fundação Getúlio Vargas.

SILVA, Ernesto (1971). História de Brasília. Brasília, Coordenada-Ed. de Brasília. Apud: FARRET, Ricardo L. (1985), O Estado, a questão territorial e as bases da implantação de Brasília. In: PAVIANI, Aldo (org.). Brasília, ideologia e realidade. São Paulo: Projetos.

SIQUEIRA, Deis (2004). Turismo na encruzilhada. Brasília: UNB.(prelo)

THOMPSON, Edward P.(1979) Tiempo, diciplina de trabajo y capitalismo industrial. In: Tradición, revuelta y consciência de classe. Barcelona, Grijalbo. Apud: 
SANT'ANA, Denise Bernuzzi de. (1994). O prazer justificado. História e lazer. São Paulo: Marco Zero.

VIEITEZ, Candido Giraldez.(2002) Marx, o trabalho e a evolução do lazer. In: BRUHNS, Heloisa Turini. (org.). Lazer e ciências sociais: diálogos pertinentes. São Paulo: Chronos (coleção: Lazer, esporte \& sociedade.)

VITOR, E. D’Almeida (1980). História de Brasília. Brasília, DF, Thesaurus Editora.

WAICHMAN, Pablo.(2003) Tempo Livre e recreação. Campinas, São Paulo: Papirus. $4^{\circ}$ ed.

CDs:

PADILHA, Valquíria, (2004). Módulo: gestão em lazer, Centro de Excelência em Turismo, curso de especialização: Turismo, cultura e lazer, UNB (1 CD)

\section{Sites:}

http://www.setur.df.gov.br> . Acesso em 22 out. 2004

http://www.setur.df.gov.br/ acesso em: 12 de abril de 2005 


\section{APÊNDICE A - ROTEIRO DE ENTREVISTA:}

Entrevista número:

1. Gênero: ( ) masculino ( ) feminino

2. Idade:

3. Profissão:

4. Local onde trabalha:

5. Faixa salarial individual mensal: (ter uma calculadora à mão e considerar o salário mínimo de $\mathrm{R} \$ 260,00$ )

a) ( ) de 10 a 15 salários mínimos

b) ( ) de 16 a 21 salários mínimos

c ( ) de 22 a 27 salários mínimos

d) ( ) de 28 a 32 salários mínimos

e) ( ) de 33 a 38 salários mínimos

f) ( ) de 39 a 43 salários mínimos

g) ( ) de 44 a 49 salários mínimos

h) ( ) de 50 a 55 salários mínimos

i) ( ) de 56 a 61 salários mínimos

j) ( ) mais de 61 salários mínimos

k ( ) mão soube informar

1) ( ) não quis informar

6) Grau de instrução:
a) ( ) Superior completo
b) ( ) Especialização incompleta
c) ( ) Especialização completa
d) ( ) Mestrado incompleto
e) ( ) Mestrado completo
f) ( ) Doutorado incompleto
g) ( ) Doutorado completo
h) ( ) Pós-Doutorado incompleto
i) ( ) Pós-Doutorado completo 
7) Grau de instrução do pai:
a) ( ) Primeiro Grau incompleto
b) ( ) Primeiro Grau completo
c) ( ) Segundo Grau incompleto
d) ( ) Segundo Grau completo
e) ( ) Superior incompleto
f) ( ) Superior completo
g) ( ) Especialização incompleta
h) ( ) Especialização completa
i) ( ) Mestrado incompleto
j) ( ) Mestrado completo
1) ( ) Doutorado incompleto
m) ( ) Doutorado completo
n) ( ) Pós-Doutorado incompleto
o) ( ) Pós-Doutorado completo

8) Grau de instrução da mãe:
a) ( ) Primeiro Grau incompleto
b) ( ) Primeiro Grau completo
c) ( ) Segundo Grau incompleto
d) ( ) Segundo Grau completo
e) ( ) Superior incompleto
f) ( ) Superior completo
g) ( ) Especialização incompleta
h) ( ) Especialização completa
i) ( ) Mestrado incompleto
j) ( ) Mestrado completo
1) ( ) Doutorado incompleto
m) ( ) Doutorado completo
n) ( ) Pós-Doutorado incompleto
o) ( ) Pós-Doutorado completo 
๑9) Como você definiria lazer, ócio e tempo livre?

10) 0 que você mais gosta de fazer no seu tempo de lazer?

12) Existe alguma coisa que você gostaria de fazer no seu tempo livre mas você não faz? Por quê? 0 que te impede de fazer?

13) Quais são os lugares de lazer que você mais gosta em Brasília?

14) Quais são os lugares de lazer que você mais gosta fora de Brasília?

15) 0 que você tem de lazer para fazer na sua casa?

16) Como você definiria seu gosto por:
a) música
b) teatro:
c) cinema:
d) arte:
e) dança:
f) literatura:
g) jogo(baralho, jogo da vida, jogos eletrônicos...):
h) esporte(assistir):
i) revista:
j) programa de TV:

17) Na sua casa, qual é a quantidade de cada um desses itens?
a) Carros:
b) Televisão:
c) Videocassete:
d) DVD:
e) Home theatre:
f) Aparelho Telefone:
g) Geladeira:
h) Computador: 
i) Aparelho Celular:_

k) Banheiros: j) Moto:

1) Empregados:

18) 0 que você acha das opções de lazer que existem em Brasília? Comente.

19) Você viajou entre Janeiro de 2004 e março de 2005?

( ) $\operatorname{sim}(\quad)$ não

20) Se sim,
a) para onde?
b) por quê?
c) com quem?
d) como? (meios de transporte):

21) Você pratica algum esporte? ( ) sim ( ) não

22) Se sim,
a) qual? _
b) onde?
c) por quê?
d) com que

freqüência?

23) Se não, por quê?

24) Você tem algum hobby? ( ) sim ( ) não

25) Se sim, qual?

26) Você é livre no seu tempo livre? Por quê?

27) Qual é o lazer mais caro que você já fez e/ou faz?

28) Qual é o lazer mais barato que você já fez e/ou faz?

29) Lazer é importante? Por quê?

30) Você se considera como membro da elite intelectual de Brasília? 
31) De tudo isso que nós falamos, você gostaria de acrescentar ou comentar alguma coisa? 


\section{APENDICE B - MAPA DE BRASÍLIA}

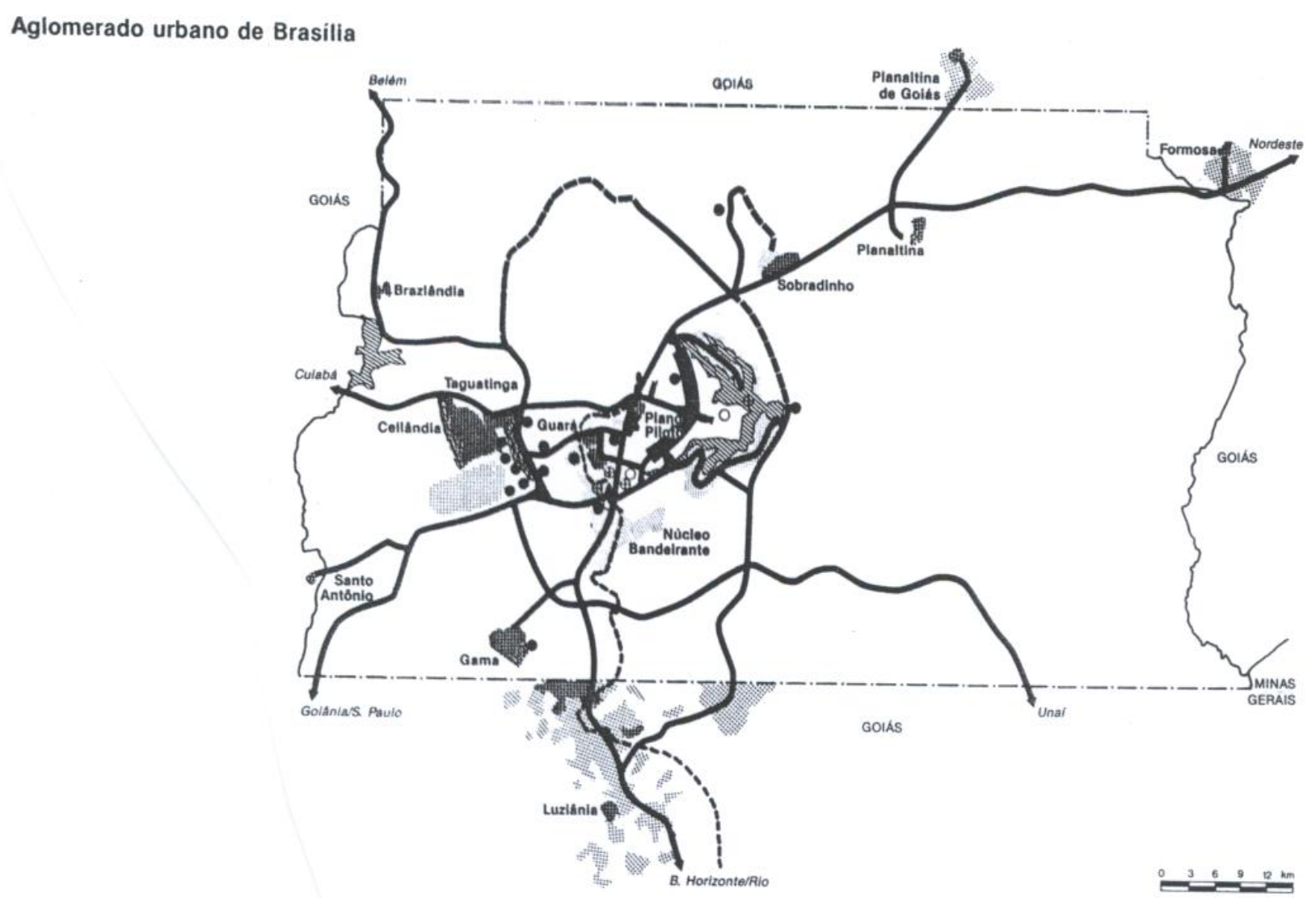

